\title{
Irilen på Øverby i Vingulmark
}

\begin{abstract}
This article presents the first interpretation of a 5 th century proto-Norse runic inscription discovered in 2017 at Øverby, Østfold, Norway: "Cut runes in, skilled iril, for Isni”. The meaning of the word iril is discussed in light of the ten other proto-Norse inscriptions in Scandinavia where irils are mentioned. Through analysis of the language, history, archaeology and landscape context of all the iril inscriptions, we argue that the iril in the Roman and Migration period was a military leader, an earl, subordinate to a King. The iril at Øverby was Earl in the medieval shire of Vingulmark. The Earls in this period were located in strategic places in the outskirts of larger habitation areas close to the shire borders. The findings are set in context with among other Danish bog offering sites. We consider the iril a military leader for major warrior groups that fought in Scandinavia and on the continent 1500-1800 years ago.
\end{abstract}

\section{Innledning}

Sommeren 2017 dukket det opp noe såpass sjeldent som en runestein fra 400-tallet på gården Øverby i Rakkestad, Østfold. Innskriften består av minst 35 mer eller mindre sikre runer fordelt over to av steinens sider og over tre linjer. I denne artikkelen presenterer vi det første forslaget til lesning og tolkning av innskriften, som i normalisert form lyder: lü irilas raskaR rūnōR in(n) Isni «Hogg raske/dyktige iril runer inn for Isni!». Vi vil diskutere den foreslåtte lesningen i lys av den arkeologiske konteksten som omfatter jernaldermiljøet på gården Øverby i Rakkestad og i lys av de øvrige irilar/erilan-innskriftene (i alt 10 sikre urnordiske innskrifter i Skandinavia). Til sist vil vi utføre landskapsanalyser med mål om å forstå hva det innebar å være en iril i eldre jernalder (figur 1).

Begrepet iril har vært forstått som en runemester, jarl og erul, og de to første tolkningene har vært ansett som de mest sannsynlige (Bugge 1891:100-102; Spurkland 2001). Noen har tolket irilen som en militær-religiøs leder (Herschend 2005:95), andre som en kultisk leder knyttet til Odinkult (Sundquist 2009). Det siste større arbeidet ble gjort i forbindelse med et nytt erilar-funn i Sverige i 2009. Alf Morten Axboe og Magnus Källström (Axboe og Källström 2013) fremhevet da to retninger for tolkningen av begrepet irilar/erilar; som en

\footnotetext{
Kontakt: Karoline Kjesrud, E-post: karoline.kjesrud@khm.uio.no

${ }^{1}$ Kulturhistorisk museum, Universitetet i Oslo.

${ }^{2}$ Institutt for litteratur, områdestudier og europeiske språk, Universitetet i Oslo.

${ }^{3}$ Østfold fylkeskommune
} 


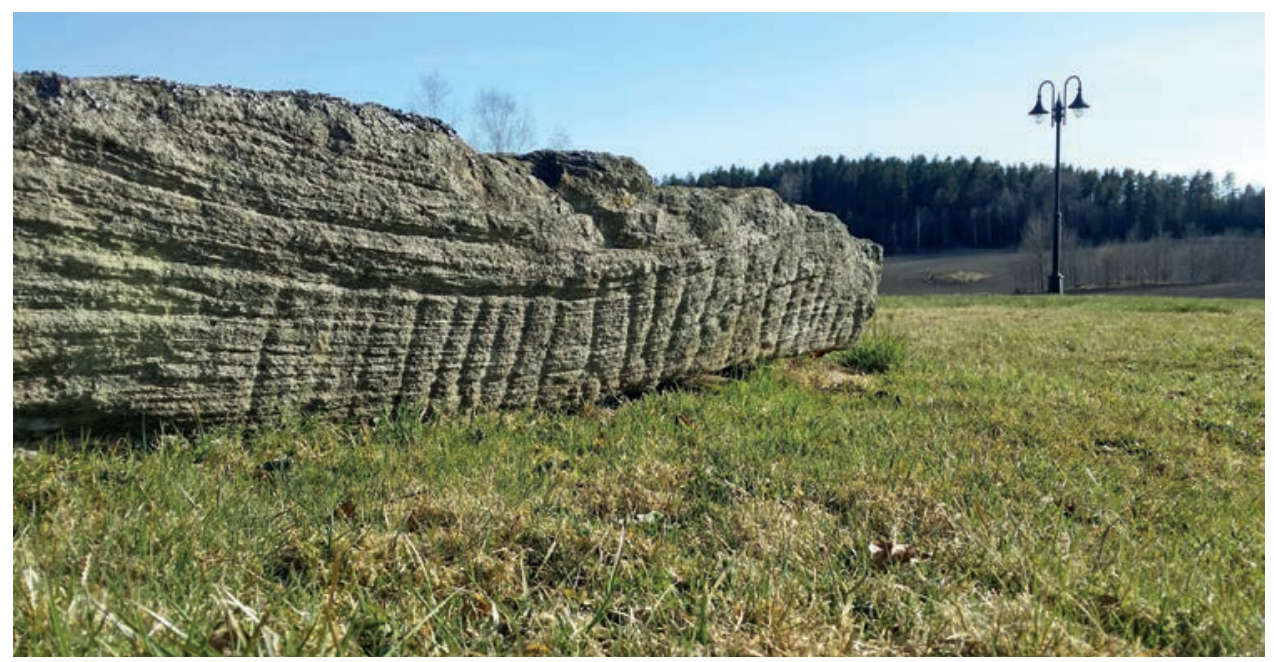

Figur 1. Runesteinen på Øverby med Sparreåsen i bakgrunnen, der den opprinnelig stod. Foto: Emil Omenås Øvstedal.

kultisk eller militær leder. I liten grad er irilaR-innskriftene og andre runefunn blitt benyttet som kilde til politisk og militær historie, slik vi skal gjøre her. Noen unntak finnes.

Den australske germanisten Bernard Mees (2003) har foreslått et tidlig germansk hierarki med en Grosskönig som øverste leder, en Kleinkönig og en Heerkönig på nivået under ham, under Kleinkönig en prest, og under Heerkönig en Troopkommander (erilaR), og under ham igjen en noble follower (pewar) (Mees 2003). Modellen er interessant, men kildegrunnlaget og argumentasjonen som leder ham dit, er uklar. Den romerske historikeren Tacitus (ca. 56-120 e.Kr.) opplyste i år 98 at kongene blant germanerne ble valgt ut fra byrd, og militære ledere ut fra egnethet - Reges ex nobilitate, duces ex virtute sumunt (Germania kap.7). Vi vil argumentere for at irilan-innskriftene samlet kan belyse politisk, militær og rettslig organisering i Viken og Skandinavia i eldre jernalder, og dermed undersøke hva Øverbyinnskriften kan fortelle oss om politisk og militær organisering i Vingulmark.

\section{Øverbysteinen: oppdagelsen}

I mai 2017 fikk Østfold fylkeskommune en henvendelse fra Rakkestad avis som skulle trykke en sak om en mulig runestein på gården Øverby (gnr. 83/7) (trykket 6.7.2017) (Berg 2017). Avisen ønsket fylkeskonservatorens mening om den, og det ble avtalt befaring med grunneierne Randi og Olav Schie, og Emil Omenås Øvstedal fra nabogården, som hadde sendt inn tipset. Runene var imidlertid blitt oppdaget av brødrene Olav og Per Schie lenge før. Allerede tidlig på 1990-tallet hadde Olav lagt merke til strekene som trådte frem når sollyset kom inn på riktig måte. På et tidspunkt hadde han forsøkt å gjøre arkeologer oppmerksomme på tegnene, men beskjeden nådde ikke frem til dem som kunne ha fulgt opp. Det var derfor et lykketreff at Emil Omenås Øvstedal også fikk øynene opp for runene, og kontaktet avisen. 
Funn av runesteiner er ikke noen dagligdags hendelse. Sist gang et runemonument fra samme periode ble funnet, var i 2008, i Hogganvik i Mandal i Vest-Agder (Glørstad mfl. 2011; Knirk 2011). Før den var det 70 år siden sist, da Rosselandsteinen ble funnet i 1947 på Vestlandet (Marstrander 1952). Til å begynne med var Fylkeskonservatoren usikker på om innskriften var ekte. Kulturhistorisk museum i Oslo ble derfor kontaktet 29. august 2017, og runologer og filologer som så bildene, mente innskriften viste runer fra den eldre futharken. I oktober samme år møttes grunneiere, nabo, fylkeskonservatoren og forskere fra museet på Øverby, og de synlige runene på steinen ble skannet.

Hvor steinen opprinnelig stod, er det ingen som vet nøyaktig. Ifølge Olav Schie hentet hans morfar August Øverby den fra Sparreåsen, vest for Øverby. Et mulig opprinnelsessted peker seg ut: I nordenden av Sparreåsen er det kjent et gravfelt (Askeladden ID 77750). Her passerte den gamle ferdselsåren mellom Hem og Øverby. Gravfeltet er nå jevnet med jorden, men besto i 1966 av tre synlige hauger, i tillegg til at en fjerde da nylig var overpløyd. Steinen ble fraktet til tunet og brukt som trappestein da våningshuset på Øverby nordre ble bygget i 1907. Steinen ble plassert med runeinnskriften inn mot husveggen, slik at runene ikke kunne sees. Da det ble bygget nytt våningshus i 1991, ble steinen flyttet til plenen der den ligger i dag. Den ble lagt på to korte tømmerstokker og tatt i bruk som hvilebenk.

\section{Beskrivelse av Øverbysteinen}

Steinen er $252 \mathrm{~cm}$ lang og 112,5 cm bred. Tykkelsen varierer fra $20 \mathrm{~cm}$ til $33 \mathrm{~cm}$. Bergarten er båndgneis som er vanlig i dette området. Steinen er flat, og er blitt lett tilhugget i nyere tid i den antatte øvre del, trolig for å passe i trappen. Øverbysteinen har sannsynligvis stått oppreist. Det indikeres av innskriftens plassering til den «øvre» $2 / 3$ av steinen, slik at inntil 1/3 kan ha stått i bakken eller på et steinfundament uten å skjule innskriften. Mange runesteiner fra denne perioden har vært oppreist (f.eks. steinene i Tune, Hogganvik, Elgesem, Einang og Kjølevik).

Runeinnskriften befinner seg på kantsiden (A-siden) og den ene flatsiden (B-siden) (= nåværende underside). På kantsiden er det én linje med runer, på flatsiden er det to linjer som er plassert langt fra hverandre, og som ikke synes å ha umiddelbar sammenheng. Det finnes flere eksempler på innskrifter der linjene ikke alltid står i en sammenheng med hverandre. For eksempel er det flere linjer på steinen som må leses separat på Hogganviksteinen som ble funnet i Mandal i 2008 (Knirk 2011). Innskriften på Øverbysteinens linje 1 og 2 er tett forbundet. Runeinnskriften ser her ut til å være nøye planlagt, og stavene møter hverandre nesten én for én på henholdsvis flatside og kantside. Innskriften på kantsiden starter noe høyere oppe enn innskriften på flatsiden. Den iøynefallende plasseringen av runene i møtet mellom kantside og flatside, og innskriftens startpunkt på kantsiden noe høyere enn på flatsiden, gjør det rimelig å gå ut fra at innskriften skal leses med kantsiden først, nedenfra og opp, leseretning høyre til venstre, deretter flatsiden ovenfra og ned, leseretning venstre til høyre, i mønster av «bustrofedon» («slik som oksen vender plogen»). En slik alternerende leseretning forekommer for eksempel også på Tunesteinen (N KJ 72).

Flatsiden er preget av store avflakinger. De lyse mineralene (kvarts og feltspat) i båndgneissen er vesentlig sterkere enn de mørke mineralene (glimmer og amfibol). Bergarten er blitt deformert slik at de lyse og de mørke mineralene danner separate bånd (foliasjon) og disse lagene kommer tydelig frem på kantsiden. Foliasjonen er den mest markante svakheten i steinen, og det er her steinen sprekker lettest opp. Runene i linje 1 går på tvers av 


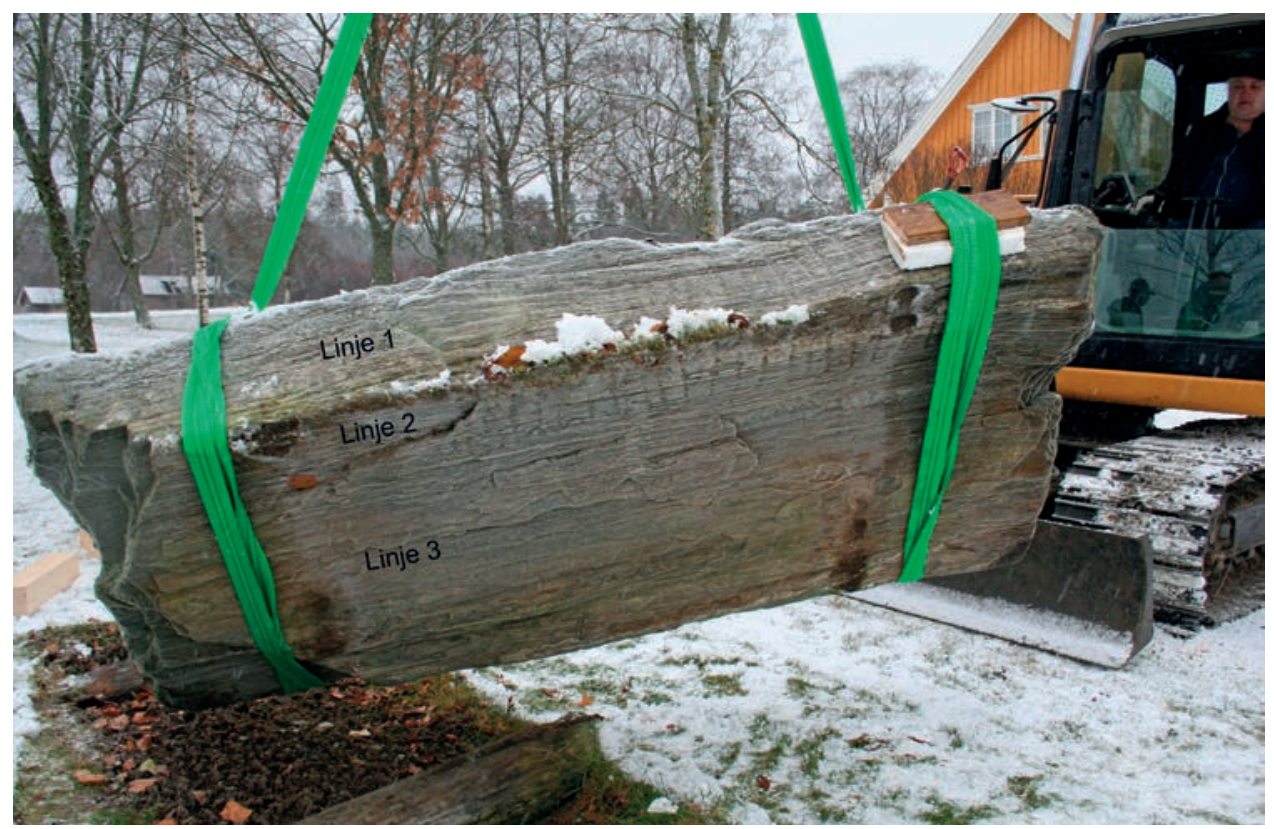

Figur 2. Runene på undersiden oppdages. Harald Martin Schie løfter den ca. 2 tonn tunge steinen $i$ båndgneiss.

foliasjonen, noe som har gjort at runene på denne siden er bedre bevart, mens runene på flatsiden er risset inn i foliasjonen, og dermed preget av oppsprekking og avflaking.

\section{Metode for dokumentasjon og identifikasjon av innskriften}

Det har vært utført feltarbeid i tre omganger i forbindelse med funnet av runesteinen. I første omgang ble det foretatt dokumentasjon av innskriften på kantsiden i form av et skann med håndholdt skanner og fotogrammetri, $\mathrm{i}$ tillegg til ordinær manuell undersøkelse med kunstig lys og skyggespill. I den manuelle undersøkelsen ble det avdekket runer også på undersiden av steinen. Den to tonn tunge steinen ble derfor snudd rundt maskinelt i neste omgang, og en lengre, men nokså skadet, innskrift ble manuelt undersøkt (figur 2). I tredje omgang ble steinen snudd for andre gang, og en høyoppløst skanning av hele innskriften ble gjennomført. Målene for den digitale dokumentasjonen var: 1) å oppnå et generelt 3D-oversiktsskann av runesteinens geometri, 2) å oppnå et nøyaktig 3D-skann av høy kvalitet av overflatene som har runeinnskrift, og til slutt 3) bruke disse dataene for å identifisere runene og tolke runeinnskriften.

Magne Samdal (KHM, UiO) sørget for et grunnleggende datasett for en fotogrammetri 3D-modell av hele runesteinen. Bjarte Einar Aarseth (KHM, UiO) utførte en strukturert lysskanning for å innhente de nødvendige dataene for mål nummer 2, og fokuserte på områdene med runer. For det tredje målet brukte vi kun dataene fra lysskanningen, fordi de ga best mulig utgangspunkt for å tyde de individuelle runene. 
Fotogrammetri er en dokumentasjonsmetode der en tredimensjonal rekonstruksjon av et objekt lages ved hjelp av et sett med bilder som dekker objektets overflate. Den strukturerte lysskanningen ble utført med en «ATOS Core» lysskanner, som benytter tre optiske komponenter: to kameraer og en kombinert kamera/mønstret lysprosjektor. Kameraenes og projektorens plassering og synsvinkler er kjent og kalibrert på skanneren. Derfor kan skanneren produsere meget presise mål av objektets overflate. Små (ø 1,5 mm) referanseprikker er plassert direkte på overflaten av objektet, og kalibrerte kontrollpunkter (TRIPOP) er plassert rundt. Disse punktene danner et referansesystem som er nødvendig for å hjelpe skanneren til å forstå geometrien samt produsere faktiske mål av objektet. Lysskanneren sender ut et lys i raskt skiftende mønstre mot objektsoverflaten. Fra dette mønsteret kan skanneren forstå konturene av overflaten og registrere dem som punkter i en tett punktsky. Disse dataene kan deretter bli prosessert til en digital overflatemaske. Overflaten blir til ved triangulering, det vil si at programvaren trekker linjer mellom tre punkter, slik at det dannes polygoner som knyttes sammen. Oppløsningen til lysskanneren tilsvarer ca. 400 punkter per mm². Det skaper store datamengder, som krever kraftige datamaskiner. For å fremkalle en tett punktsky og digital overflatemaske har vi brukt GOM's ATOS Professional programvare. Strukturert lysskanning er blitt brukt før på runesteinene fra Jelling i Danmark (Trudsø 2008), og andre relaterte teknologier er blitt brukt for å dokumentere flere runesteiner $i$ Sverige (Åhfeldt 2010, 2013). Nylig er den norske Kulisteinen blitt skannet på nytt med 25 punkter per $\mathrm{mm}^{2}$ (Knirk 2018:97).

Etter at punktskyene var blitt prosessert til digitale overflatemasker, kunne tre typer digitale analyser oppnås: virtuell skyggeprojeksjon (VSP), digital terrengmodell (DEM) og «surface defect analysis» (SDA). For å redusere prosesseringstiden for dataene og for å identifisere variasjoner i den naturlige overflaten på steinen ble den digitale overflatemasken delt opp i mindre, overlappende deler. Slik ble både enkelte deler og hele overflaten prosessert, og disse ble sammenlignet med hverandre. Mindre deler gjorde at vi ikke trengte å redusere kvaliteten på den digitale overflatemasken og dermed runesteinens faktiske geometri. Resultatene er basert på data av høy kvalitet og uten endret geometri.

For VSP importerte vi dataene i 3D-programvaren Blender for produksjon av tredimensjonale simuleringer og såkalte «renderinger». Den digitale overflatemasken ble posisjonert under et virtuelt kamera og omgitt med virtuelt lyst i intervaller på $45^{\circ}$. Programvaren tillater avansert lyssetting som gir full kontroll over det virtuelle miljøet inkludert skyggesetting.

For å utarbeide en DEM (Digital Elevation Model, digital høydemodell) brukte vi programvaren GOM Inspect Professional. De faktiske målene i de innhentede dataene ble brukt til å kalkulere et punkts høyde i forhold til andre punkter. Dataproduksjonen fra denne prosessen er visuell med en fargegradient som dekker den digitale overflatemasken, og der fargene representerer forskjellige høyder.

SDA er et datatolkningsverktøy inkludert i GOM Inspect Professional som kan identifisere feil (for eksempel bulker eller avtrykk) på en overflate ved å ta en måling mellom to punkter på en linje. Linjen må være definert av en maksimumdistanse større enn feilen som skal måles. Programvaren kan slik kalkulere høydevariasjoner i den nominelle overflaten. I likhet med en DEM vil programvaren vise forskjeller i høyde ut fra en fargegradient. En DEM kalkulerer om et punkt er høyere eller lavere enn punkter omkring, uten utgangspunkt i en nominell overflate. Dette i motsetning til en SDA, hvor en bestemt høyde blir ansett som 


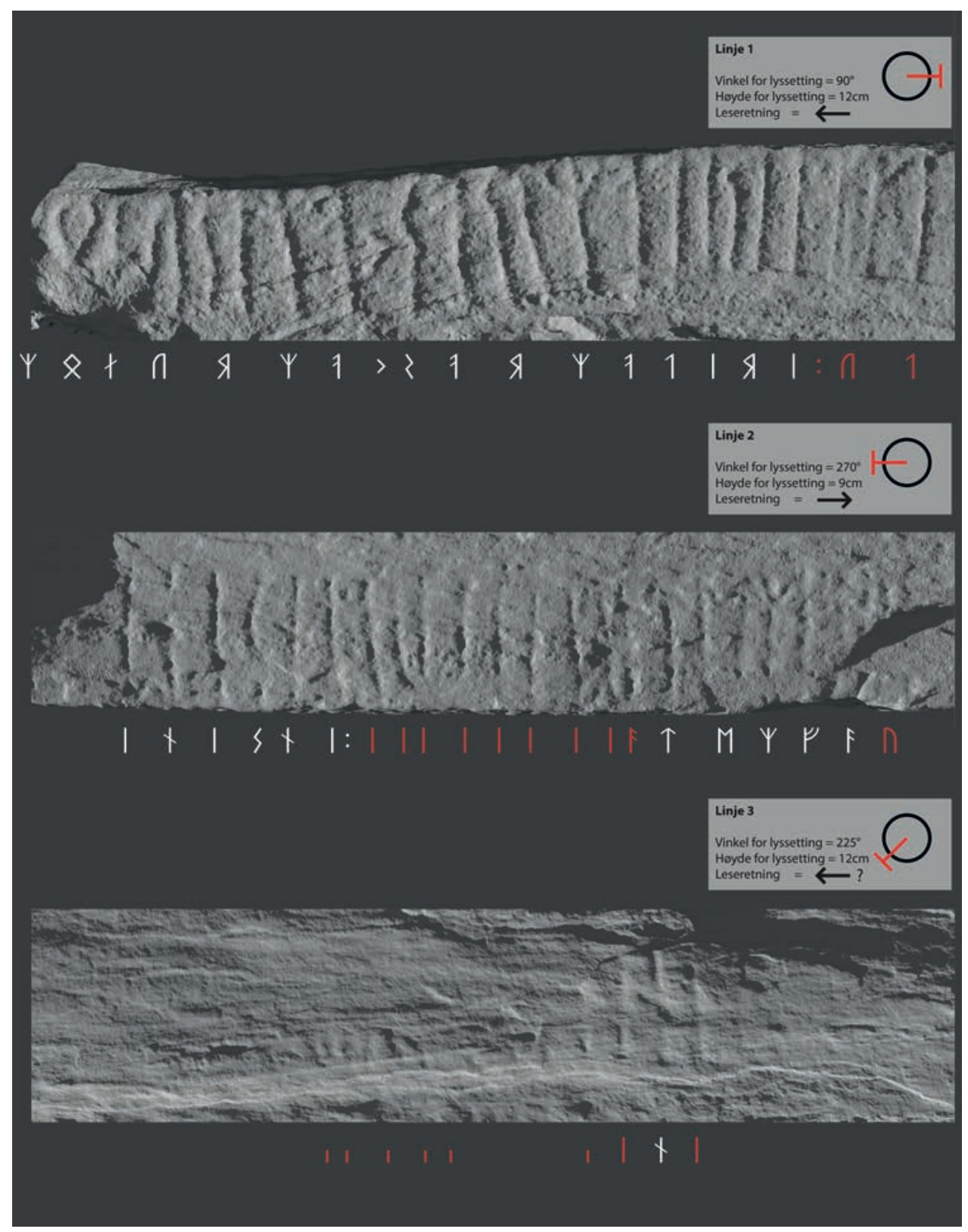

Figur 3. Translitterering av Øverbysteinen. Rødt indikerer usikker lesning.

\section{A 1: !̣u:irilanraskarrunor}

$B$ 2: inisni : ....... .. ạterfạụ

$B$ 3: ịnị

lü irilaR raskaR rūnōe in(n) İsni, «Hogg raske/dyktige iril runer inn for Isni!» 
gjeldende, og samtlige mål blir tatt med utgangspunkt i den. For våre analyser betyr det at den maksimale linjedistansen ble satt til den gjennomsnittlige bredden av en rune på steinen. Programvaren identifiserte derfor bare mulige runer som dukket opp som anomalier i forhold til den nominelle overflaten på runesteinen. Dataene som er produsert ut fra disse tre metodene, ble eksportert som 2D-bilder (figur 3). 3D-modellen og 2D-bildene fra steinens ulike seksjoner og med ulike lyssettinger har vært grunnlaget for identifiseringen av runene, særlig i linje 2. Det meste av runeinnskriften på steinens kantside, linje 1 og linje 3, ble identifisert med lyssetting og skyggeeffekter i felt.

\section{Resultater}

\section{Translitterering og lesning}

Linje 1 består av 19 runer som er opptil $19 \mathrm{~cm}$ høye. Runenes toppunkt går i flukt med øverste punkt på kantsiden og er noe slitt der runene møtes i overgangen mellom kant- og flatside. I translitterering og lesning representerer fet skrift de leste runene, punkt under bokstaven betyr at runen er usikker.

\section{Linje 1: lụ:irilarraskaRrunoR}

Partiet fra rune nr. 3 i til rune nr. $17 \mathbf{n}$ er godt bevart, og innskriften her er grei å identifisere. Nedre del av staven på rune nr. 17, under den diagonale kvisten som krysser omtrent midt på linja, er skallet vekk. Rune nr. 18 er avskallet i nedre del, og det er kun den øverste formen av o-runen som er synlig. Det er likevel ikke tvil om lesningen av runen som en $\mathbf{o}$. På rune nr. 19 er det bare synlig en diagonal kvist som peker opp og mot høyre i høyde med

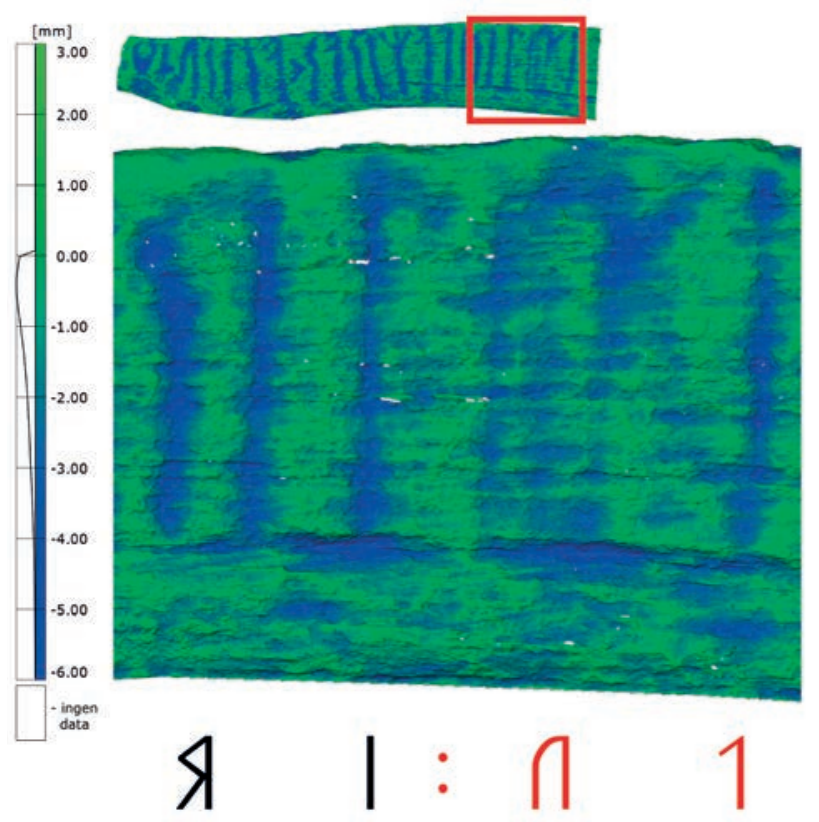

Figur 4. Høydemodell av første del av linje 1 .

Leseretning fra høyre mot venstre. De to første runene er usikre. Vi mener å identifisere et interpunksjonstegn bestående av to punkter som styrker lesningen av lu : . En initial e-rune i irilan er vanskelig grunnet manglende høyerestilt vinkel fra det øverste punktet. 
o-runens øvre del. Kvisten som peker opp og mot høyre, må være den høyrestilte kvisten i en $\mathbf{R}$, og siste del av linje 1 leses som runoR, rūnōR. Skadene på kantsidens øvre del har tilsynelatende ikke fort med seg tapet av flere runer.

Lesningen av de to første runene i linje 1 er usikker, da overflaten her er mer slitt, og huggmerkene ikke er like dype som på resten av innskriften, med unntak av de to første stavene og en skråstilt strek mellom dem. Den digitale dokumentasjonen viser dybdeforskjellene tydeligere, og det synes klart at det dreier seg om to staver og én bistav. En skråstilt strek er trukket mellom den første og den andre staven fra det øverste punktet på den første staven og deretter diagonalt ned mot venstre, ca. 1/4 stavlengde. Den er dypt hugget, og det er litt uklart hvor godt festet den er i den første stavens øverste punkt. Det er en liten skade som gjør at de øverste punktene på både kvist og stav er svakere her. Manuell undersøkelse gir inntrykk av at de henger sammen. Vi har vurdert om denne streken kunne være bistaven til stav nr. 2, og om det i så fall kunne dreie seg om den høyrestilte kvisten på en R-rune, men det finnes ingen antydninger til en motstående venstrestilt kvist ut fra staven. Kvistlengdene varierer på alle runene i hele den første linjen. Det åpner for å lese rune nr. 1 som l (figur 4).

Mellom stav nr. 2 og den etterfølgende bistaven er det spor vi forstår som skader i steinens overflate, og ikke som hugget. Bredden og dybden på sporene er ujevn.

De fleste irilan/erilan-innskrifter er foreslått lest som en formel med ek foran, ek irilan eller ek erilan, slik det forekommer for eksempel på Bratsbergspenna (KJ 16), Veblungsnes (KJ 56) og By (KJ 71). Formelen blir i tolkningen av nye funn ofte foreslått på bakgrunn av andre funn, og ikke nødvendigvis på bakgrunn av hva som faktisk er bevart av runer i den aktuelle innskriften. I flere tilfeller forekommer bare en e før erilar, og andre ganger forekommer bistaven i ligaturen på feil stav. Runologer har tolket slike varianter som «feilristninger». Vi har vurdert om de første to stavene og den ene bistaven i linje 1 kan representere en ek-ligatur, men det er ingen spor etter en skrånende kvist fra den andre staven ned mot høyre som møter bistaven til den første staven.

Fra den andre stavens toppunkt går en skrålinje ned mot venstre som jevner seg ut til en rett linje. Bistaven har et noe høyere avslutningspunkt enn den skrånende linjen, men fortsetter ikke i samme høyde som de foregående eller etterfølgende stavene. Stav nummer 2 med bistav kan følgelig leses som en u-rune.

De to første tegnene på kantsiden av Øverbysteinen foreslås dermed lest som lu. Denne lesningen er usikker, og vi kan ikke utelukke at de første huggede linjer kan være en ukjent ek-ligatur, eller en «feilristning». Vi velger likevel å ta utgangspunkt i de innhuggede sporene, og da er lesningen lu å foretrekke. Like etter de to første runetegnene er det en fordypning midt mellom bistaven i den foreslåtte u-runen og den neste staven, nokså høyt oppe. Dette punktet har vi vurdert om kan være det nederste punktet i en vinklet e-rune (også foreslått av Lisbeth Imer og Jonas Nordby), i og med at skrivemåten irilan/erilaR varierer i det samlede korpuset. Den digitale dokumentasjonen viser at det kan være mulig å se en fordypning fra punktet og opp til venstre mot den neste staven, men tilsvarende vinkel fra punktet opp mot staven til høyre finnes det ingen antydninger til. Snarere viser dokumentasjonen spor av enda et punkt lenger nede i samme linje som det øverst punktet, som indikerer et interpunksjonstegn. Det øverste punktet er noe dypere enn det nederste. Det kan ha sammenheng med den øvrige slitasjen i det nedre området.

Det er lite trolig at rune nr. 3 kan være noe annet enn en i-rune. Det passer for øvrig godt med korpuset av irilan/erilan-innskrifter. Tre steinmonumenter fra Norge har gjengitt irilaR 
(Rosseland (N KJ 69), Veblungsnes (N KJ 56) og By (N KJ 71)) og ikke erila (som er typisk for løsfunnene, for eksempel Bratsbergspenna (N KJ 16) og spydskaftet fra Kragehul (DR 196 U)). Järsbergmonumentet fra Kristinehamn i Värmland (Vr 1) er lest erilar. Det øverste partiet i e-runen er skadet, men er foreslått lest som en binderune êr (Krause og Jankuhn 1966, Imer 2015 [2007]). Linje 1 må leses i sammenheng med linjene 2 og 3 på flatsiden (B-siden).

Runeinnskriften i begge linjene på B-siden er svært vanskelige å lese på grunn av oppsprekkingen langs steinens foliasjoner og værslitasje. De vertikale linjene er de best bevarte i steinens overflate. Skadene må ha gått ut over kvistene spesielt, mens stavene er bedre bevart. Der kvistene er hugget inn i steinens sterkeste punkter (steinens lyse partier), er også de bevart, men mange kvister er blitt borte. Den digitale dokumentasjonen har til en viss grad gjort det mulig å skille ut dybdeforskjeller mellom huggede furer, naturlige furer og skader. Plasseringen av runene i linje 2 begynner lenger «nede» enn der linje 1 slutter, 22,2 $\mathrm{cm}$ fra steinens venstre kant og i høyde med r-runen i runor i linje 1. Det er ikke spor etter runer i forkant. Runene i linje 2 er ca. $24 \mathrm{~cm}$ høye, og nedre del av runetegnene møter toppunktene i linje 1. De 5-8 nederste $\mathrm{cm}$ av steinens flatside som vender mot kantsiden, er imidlertid preget av store avflakinger. Linje 3 opptrer i god avstand $(39,7 \mathrm{~cm})$ fra linje $2 \mathrm{og}$ $57,6 \mathrm{~cm}$ inn mot midten fra venstre kant. Her er runene ca. $19 \mathrm{~cm}$ høye.

\section{Linje 2: inisni:[.......]ạterfạu}

De seks første runetegnene i linje 2 ble delvis identifisert i felten, men den digitale dokumentasjonen var nødvendig for å klarere at de to første runene avgjort er i og $\mathbf{n}$, og ikke $\mathbf{h}$. Sekvensen leses følgelig som inisni. Kvisten på den andre runen er tydelig, det samme er en 3-leddet s-rune, som her står plassert i motsatt retning av s-runen i linje 1. Midt på den femte runens stav er én kvist vendt på skrå over linjen fra venstre til høyre, og en annen fra høyre til venstre. Det ser ved første øyekast ut som et kryss over staven, men kvisten fra venstre til høyre er dypere enn den fra høyre til venstre og gjør at den første anses å være den gjeldende. Det gir en n-rune. Sekvensen etterfølges av et interpunksjonstegn bestående av to prikker overfor hverandre, likedan det foreslåtte interpunksjonstegnet i linje 1. Etter interpunksjonstegnet er lesningen vanskeligere på grunn av store skader i steinens overflate. På de åtte første stavene er ingen kvister bevart. Det er dermed ikke mulig å bestemme hvilke runer det dreier seg om, bortsett fra at følgende runer kan utelukkes fordi de ikke har rette staver: o, j, k, g, s, og ng.

Den første staven er rett, den neste har et svakt innsvinget punkt omtrent midt på staven og skråner forsiktig mot høyre i nedre del. En slik form kan minne om en r-rune, men stavene er ikke tydelig forbundet i toppen. En skråstilt strek forekommer nokså høyt oppe mellom de to stavene, og kunne peke mot lesningen av en h-rune. Skråstreken forekommer imidlertid i et parti med naturlige furer som fortsetter både til høyre og venstre, og det ser ut til at den sammenfaller med en naturlig fure snarere enn en hugget linje. Tredje og fjerde stav etter interpunksjonstegnet forekommer uten synlige kvister, mens den femte og sjette staven er sammenføyet i et skadet parti. Kanskje skyldes skaden en svakhet i steinen som følge av en skråstilt kvist mellom de to stavene, i så fall ville det være en $\mathbf{h}$-rune. Fra den neste stavens nederste punkt kan det se ut til å gå to oppadskrånende streker som antas å være del av en skade i det nedre partiet. Den ene av de to er dypere enn den andre, og kan utgjøre nedre del av en b-rune, men det ser ikke ut til at den øverste delen av runen skråner 
tilsvarende, så det virker problematisk. Deretter følger en ny stav med en synlig skråstilt kvist ned mot høyre i stavens øverste parti, det kan være en a-rune der den øverste kvisten i så fall er tapt. En noe grunnere linje fra kvistens ytterpunkt og skrånende inn mot staven kan imidlertid skimtes, og det kunne indikere en $\mathbf{b}$. Deretter følger runene: $\mathbf{t} \mathbf{e} \mathbf{R}$, en $\mathbf{f}$ der nedre del av staven er skadet, samt en mulig a med skadet nedre del av staven. De to kvistene på a-runen peker skrått ned mot høyre der de synes å ende i en ny stav, etterfulgt av nok en tett påfølgende stav som skråner noe i toppen, og således peker mot en u-rune.

\section{Linje 3: ịnị}

Den tredje linjen, midt på steinens flatside, er sterkt skadet. Den kan ha fortsatt i begge retninger, og de to $\mathbf{i}$-stavene kan ha hatt andre bistaver knyttet til seg og dermed representert andre runer. Det som er bevart av runer i linje tre, kan knapt gi noen mening slik det står nå. Avstanden til linjene 1 og 2, samt skadene i forkant og etterkant av runene, gjør at de tre tegnene ikke kan leses i umiddelbar forlengelse av linje 2 .

Når de tre linjene sees under ett, får vi følgende:

\section{Linje 1: !̣̣:irilarraskaRrunor}

\section{Linje 2: inisni:[.........]ạterfạụ}

\section{Linje 3: ịnị}

Det er de usikre runene lu som også språklig sett er de mest problematiske. Michael Schulte fremhever at det urnordiske språket er formelpreget, og at setningsledd som verb kan utelates (2001:172). Det foreligger imidlertid en rekke gode syntaktiske grunner til å tolke de usikre runene lu som en verbalform:

1) Ordet $r \bar{u} n \bar{o} R$ synes avgjort å være direkte objekt i setningen, slik som i alle kjente innskrifter, og det er styrt av ulike verb som indikerer innskriving av runer, f.eks. wurtē rūnōR (Tjurkö), wrìtu $\overline{\bar{l}}$ rūnōR (Eikeland) og rūnō fāhī (Noleby).

Noe verb med en slik betydning er ikke umiddelbart synlig her, men tanken om at et slikt verb kunne foreligge, ble styrket av at de første runene på B-siden, som leses inisni. Denne skal trolig segmenteres $\mathrm{i}$ in og isni, og in kan da leses som in eller inn i 'inn i', jf. preposisjonen norrønt í og adverbet inn 'inn'. Syntaktisk kan begge som verbalpartikkel knyttes til et verb med betydninger som 'risse inn, føre/dikte inn' osv. En tilsynelatende parallell er bl.a. wrìtu $\tilde{\bar{l}}$ rūnōR $\tilde{\bar{a}} s n i$ ‘jeg risser/skriver inn runer for ẫ̄snī (dat.)’ (Eikeland, med nasal $\tilde{\overline{1}}<$ eldre $i n)$.

2) Sekvensen isni (foran skilletegnet :) gir derimot ingen mening, men syntaktisk sett kunne vi her vente å finne en dativform, dvs. at setningen slutter med at vi får vite for hvem runene ble laget/hugget inn, jf. den sannsynlige (men uforklarte) dativen '(for) âsnī’ ovenfor. I så fall måtte isni kunne representere et ellers ukjent (manns/kvinne)navn, f.eks. lest Īsni og altså trolig bøyd som i-stamme.

3) Det nødvendige verbet svarende til f.eks. wrîtu måtte da skjule seg i de første runene på A-siden. De er dessverre vanskelige å lese, men en sekvens lu er, som vist ovenfor, blant de mest sannsynlige. Den store fordelen med denne lesningen er at vi da kan identifisere en imperativ $l \bar{u}$ ! 'hogg' som utvilsomt er en arkaisk form av det norrøne j-verbet lýja 'hamre, slå osv.', se videre nedenfor. Skilletegnet : etter lu underbygger også lesningen av denne sekvensen som en imperativ, dvs. fulgt av en pause. 

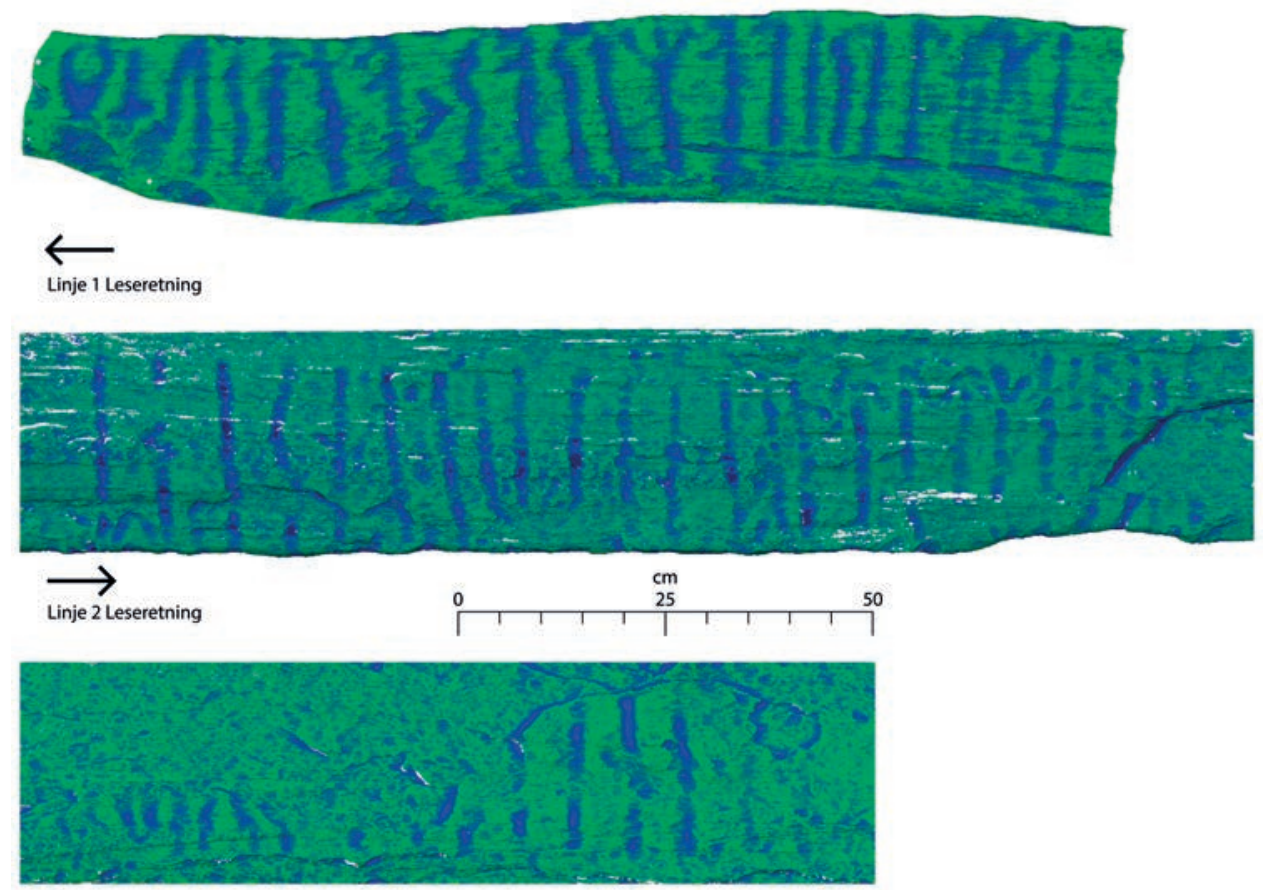

$$
\longleftarrow_{\text {Linje } 3 \text { Leseretning }}
$$

Figur 5. Høydemodell av alle linjer basert på høyoppløst skanning. Runene er opp til 5-6 mm dype (se også figur 4).

Vi får da en syntaktisk velformet setning som lyder slik: lü irilas raskaR rūnōs in(n) $\bar{I}_{\text {sni- }}$ 'hogg raske/dyktige iril runer inn for Isni!'.

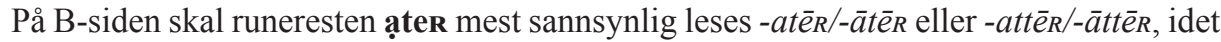
a-runen blant annet kan leses som $a$ og $\bar{a}$, og t-runen også kan leses som lang tt. Den kan videre oppfattes på følgende vis:

1) med endelsen $-\bar{e}_{R}$ som nom. pl. m. av et adjektiv med rotutlyd på -at(t)/-át(t), f.eks. flatr 'flat', hvatr 'skarp, snøgg, rask', latr 'lat, treg', -látr, f.eks. lítillátr 'smålåten, ydmyk', og vátr 'våt', jf. superlativformen sījōstēe eller ẫsijōstēe på Tunesteinen. Men det er ingen åpenbar grunn til at det i innskriften her skulle opptre en slik adjektivisk flertallsform.

2) med endelsen $-\bar{e} R$ som 2 . sg. av et verb med rotutlyd på - $t$ osv.:

a) presens indikativ av et $\overline{\mathrm{e}}$-verb.

Det eneste mulige ē-verbet synes å være játa 'si ja til', men det er vanskelig å se at dette semantisk sett skulle kunne passe inn.

b) presens konjunktiv av et sterkt verb, og her kommer vel bare gráta 'gråte' og láta 'la, tillate osv.' på tale. 
Vi ser på B-siden følgelig altfor lite til å kunne danne oss noen som helst oppfatning av hva som kan ha stått her. Det er et beklagelig faktum ikke minst fordi vi her muligens kunne ha fått vite nærmere hvorfor setningen på A-siden har en så pass spesiell syntaktisk form, det vil si er en oppfordring til å hogge inn runer.

Den innledende runesekvensen leses altså her som lu og tolkes som 2. sg. imperativ $l \bar{u}$ ! 'hogg' til et sterkt verb urnordisk inf. *lūan 'hogge, kutte, skjære'. Dette verbet kjennes i norrønt bare i omdannet svak form lýja (pret. lúði) 'hamre, banke, slå; knekke, skade, mishandle, svekke', f.eks. lýja járn 'hamre ut jern' og nyislandsk lýja 'ds.'. Det opprinnelige sterke verbet kommer imidlertid ennå til syne i norrønt ved at lýja har et sterkt perfektum partisipp lúinn, som også betyr 'utslitt, trøtt', jf. nyislandsk lúinn 'utslitt', norsk dial. luen 'utmattet' og gammelsvensk lüin 'trøtt'. Inf. lýja har følgelig erstattet eldre *lúa (< urnordisk *lūan) med $y$ fra pres. lýr, jf. norrønt flýja 'flykte' etter pres. flýr, jf. nynorsk fly 'ds.' (pret. flydde). Den opprinnelige infinitiven *lúa synes å være reflektert i nyislandsk lúa 'luke (ugras)' og færøysk lúgva (pret. lúgvaði) 'utmatte'. Preteritum hadde i norrønt trolig opprinnelig formen 3. sg. *ljó (< urnordisk *leu), jf. norrønt inf. búa, pret. bjó (< urnordisk *beu).

Som andre sterke verb er urnordisk *lūan et såkalt primært verb, det vil si at det er dannet direkte til verbalroten germansk *lū- 'hogge, kutte, skjære'. Den forekommer ellers i f.eks. norrønt lúðr m. 'uthulet stokk til å legge småbarn i, likkiste' og nynorsk lur 'benk el. platting som den underste kvernsteinen i en mølle ligger på'.

Avlyd er et språkhistorisk fenomen som betegner vokalveksel i samme ord eller forskjellige ord av samme rot i indoeuropeiske språk. Avlydstrinnet (nulltrinnet) germansk *luveksler med bl.a. germansk *lew- i f.eks. norrønt lé (obl. ljá) m. 'ljå' (< urnordisk *lewan-).

Fra en norrøn synsvinkel er adjektivet nom. m. raskaR 'rask, kvikk, effektiv osv.' en noe overraskende form. Norrønt har nemlig ingen motsvarende form, men derimot et adjektiv nom. m. roskr (akk. m. roskvan) 'dyktig, modig', som etter all sannsynlighet hører sammen med navnet på Tjalves søster Vrǫskva f., yngre Roskva (kjent som mytologiske skikkelser i Pórsdrápa), og det viser at roskr opprinnelig hadde en initial ${ }^{*} w$. Vi skal følgelig rekonstruere norrønt roskr som urnordisk nom. m. *wraskwar (med bl.a. * $a>Q$ foran den følgende $w)$, og det er egentlig en slik form man kunne forvente å finne i en urnordisk runeinnskrift som beskrivelse av en irilar.

Hvis vi derimot ser ut over norrønt, finner vi former som norsk rask 'hurtig, kvikk, sunn, frisk, djerv', færøysk raskur 'kjekk, dyktig, frisk', dansk rask 'hurtig, energisk, frisk', gammelsvensk rasker og svensk rask 'kvikk, pigg'. Siden tilsvarende former altså ikke finnes i norrønt eller nyislandsk, regnes de allment som lånt fra middelnedertysk rasch. I vestgermansk finner vi ellers middelnederlandsk rasch, nederlandsk ras, engelsk rash 'hastig, brå', gammelhøytysk rask, reski 'rask, hissig', rasko adv. 'heftig, livlig' og tysk rasch 'rask'.

Den nyoppdagede formen raskar synes imidlertid å vise at nordgermansk hadde et adjektiv tilsvarende de vestgermanske formene, slik at det kanskje ikke er nødvendig å regne gammelsvensk rasker og de øvrige formene som lånt fra nedertysk. Det er følgelig mulig å anta et felles nordvestgermansk adjektiv *raska/o- 'kvikk', og når det gjelder etymologien, kan dette være en avledning med $k$-suffiks til verbalroten germansk * ras'bevege seg raskt, fare i veg' som vi ser i norrønt rasa 'fare i vei', norsk rase 'fare voldsomt', jf. i rasende fart osv. (Falk \& Torp 1903-6, 2:96). 


\section{Datering}

Det er primært skrifthistoriske og språkhistoriske kriterier som kan datere innskriften. Ordene irilan og raskan opptrer i ikke-synkoperte former og fastslår klassisk urnordisk språk. Innskriften er hugget med runer fra den eldste futharken, 24-tegns futharken, som er belagt i innskrifter fra ca. $160 \mathrm{e.Kr}$. til ca. 700. Runerekken går gjennom store endringer som følge av språkhistorisk utvikling på 600-700-tallet, og leder gradvis til en 16-tegns futhark. Både språklige og grafematiske endringer skjer over tid, og det gjør det mulig å plassere visse av innskriftens tegn til en kronologisk utvikling av runeinventaret til bestemte perioder (Imer 2015 [2007]). Den eldste k-runen forekommer i innskriften, og plasserer følgelig innskriften før år 500. Den treleddede s-runen som er brukt, er belagt etter ca. 375/400. Det gir oss en relativ datering innenfor perioden mellom 375/400 og 500.

\section{Jernaldermiljøet på og rundt Øverby}

Flere av gårdene ved Øverby har navn som slutter på -by: Melleby, Nerby og Krosby (gårdsnummer 80-83), og dessuten retningsprefiks (mellom, nedre og øvre). Det er ikke usannsynlig at by-gårdene en gang dannet én opprinnelig gård (Johansen 1989:215). Det tyder også gårdsgrensene på (figur 6). Navneleddet -by eller -bø var i bruk i yngre jernalder i Sverige, men dateres gjerne til vikingtid i Norge (Sandnes og Stemshaug 1976; Vikstrand 2013:97; Ødegaard 2018).

På disse - by gårdene finnes spor fra alle perioder i forhistorisk tid. I tillegg har de mange kulturminner fra jernalderen: enkeltliggende gravhauger, små gravfelt, men også bosetningsspor. Ved det historiske tunet på Øverby (= dagens tun på Øverby søndre) er det gjennomført to små arkeologiske utgravninger. På to mindre felt vest for tunet på nordre Øverby fant arkeologer fra Oldsaksamlingen i 1986 et kulturlag, fire stolpehull og én kokegrop fra førromersk jernalder (T-7292:110 f.Kr.-10 e.Kr.) (Rui 1986; Johansen 1989). I 2000, da fylkesveien ble utvidet, oppdaget Olav Schie at en rekke arkeologiske strukturer lå eksponert på begge sider av veien mellom Øverby nordre og søndre. Han varslet fylkeskommunen, og samme år gjennomførte det nyopprettede Kulturhistorisk museum en arkeologisk utgravning (Askeladden ID 15323, C52487). Utgravningsfeltet omfattet to smale striper på 1-2 meters bredde på hver side av eksisterende vei (Bøckmann 2000). Det ble påvist over 30 kokegroper og 10 mulige stolpehull. Én kokegrop ble datert til førromersk jernalder (T-15119: 200-5 f.Kr.) og ett stolpehull til romertid (T-15118: 25-230 e.Kr.). Det var ikke mulig å definere helhetlige forhistoriske bygninger. Sannsynligvis representerer utgravningen i 2000 mindre deler og utkanten av et eldre tun på Øverby, med rester av bygninger og mattillaging. Tunet synes slik å ha ligget fast siden førromersk jernalder.

Det finnes flere gravminner i nærheten av det historiske tunet på Øverby. Ca. $490 \mathrm{~m} \mathrm{mot}$ vest ligger gravfeltet der runesteinen kan ha stått (Askeladden ID 77750). I 2017 ble det levert inn en korsformet spenne i bronse (aks.nummer 2017/1477) (figur 7). Funnet var gjort et halvt århundre tidligere på jordene vest for tunet, i samme tidsrom som en gravhaug var blitt fjernet fra gravfeltet ved Sparreåsen i årene noe før 1966. Spenna avsluttes i foten med et dyrehode typisk for denne spennetypen, som med få unntak bare forekommer i kvinnegraver (Røstad 2016, kap. 6 og 7). Spennen er fra folkevandringstid (periode D1, ca. 400$550 / 75$ e.Kr.). Spennen kan stamme fra gravfeltet der runesteinen kan ha stått. 


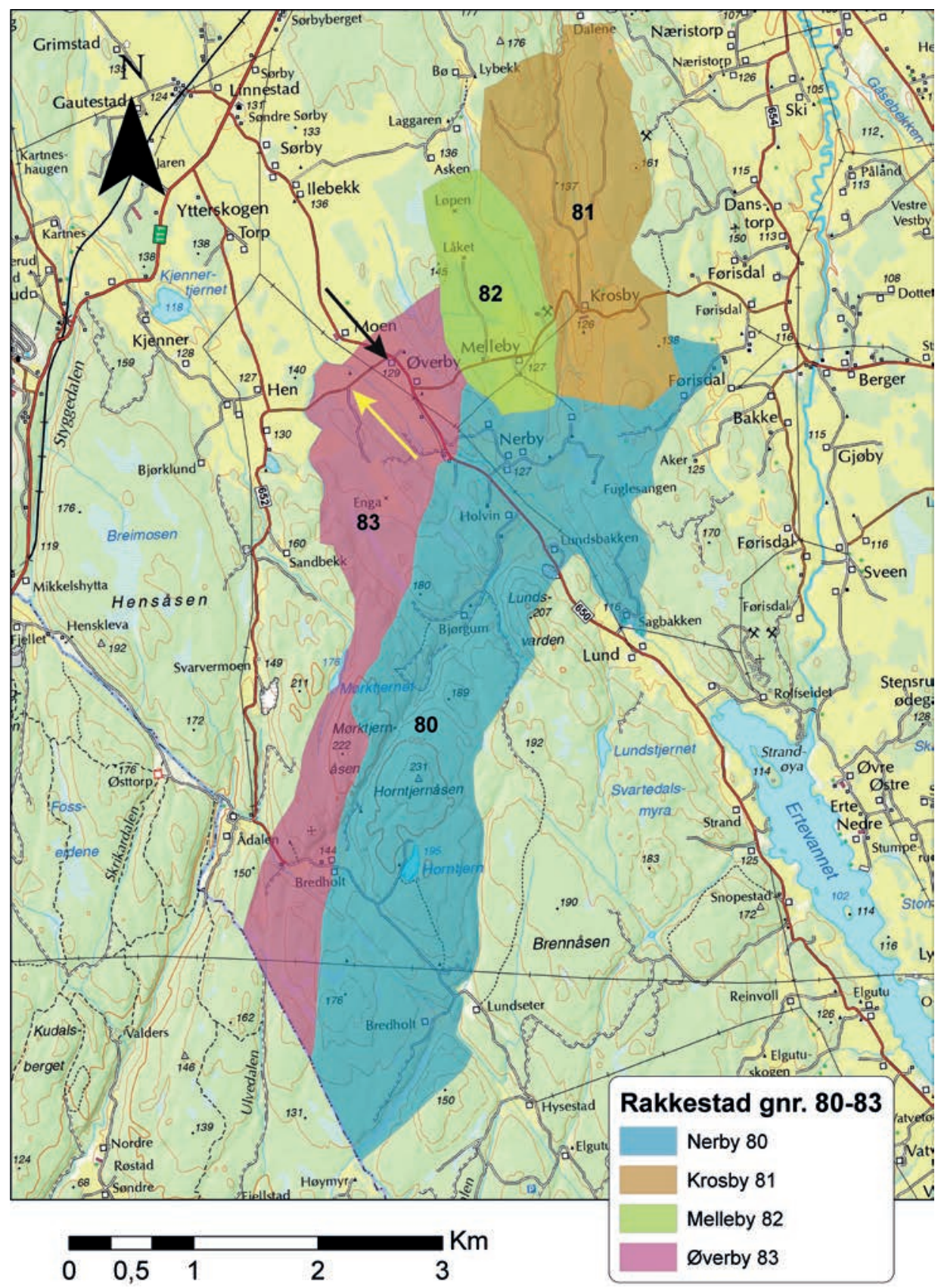

Figur 6. Øverby og nabogårdene Nerby, Melleby og Krosby kan engang ha utgjort en samlet gård, slik både grunnordet by og retningsnavnene «øvre», «nedre» og «mellom» indikerer. Svart pil viser stedet steinen lå på da den ble funnet, og gul pil hvor den opprinnelig kan ha stått. 


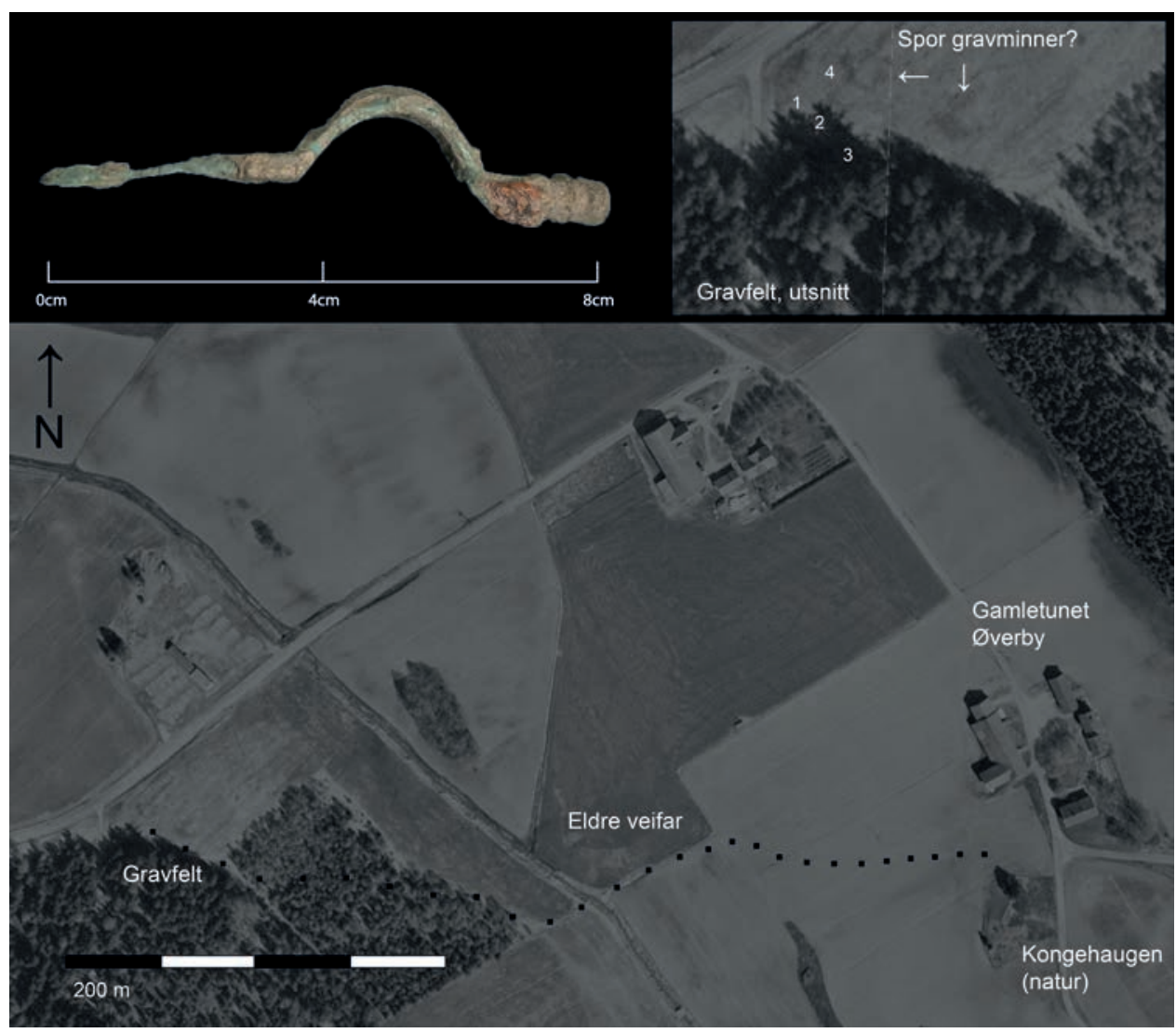

Figur 7. Korsformet spenne fra Øverby funnet på jordene vest for tunet, kanskje ved Sparreåsen (jf. rød pil figur 8). Spenna er datert til 400-525, til samme tid som runeinnskriften. Gravfeltet ved Sparreåsen besto i 1966 av to runde hauger og én langhaug, dessuten avén grav som da var fjernet. Spenna ble funnet på et jorde vest for tunet for over 50 år siden. De andre gravene på gravfeltet ble slettet lenge etter 1966. Det er derfor mulig at spennen stammer fra grav nummer 4. På flyfoto fra 1964 sees dessuten to-tre ringer på jordet nord for gravfeltet $i$ skogholtet. En av disse kan vare grav nummer 4. Flyfotoet indikerer at gravfeltet kan ha bestått av flere graver enn det som ble registrert to år senere.

Beskrivelse av gravfeltet fra ØK-registeringen i juni 1966, fra nord:

Rundhaug: 8 i diameter og 0,9 meter høy

(1 $\mathrm{m}$ SØ for $n$ r. 1): Rundhaug med forsenkning i vest (d. $9 \mathrm{~m}, \mathrm{h.} 0,8 \mathrm{~m}$ ).

(3 m ØSØ for $n r .2)$ : Langaktig haug, orientert NNØ-SSV. (l. $9 \mathrm{~m}, \mathrm{br} .7 \mathrm{~m}, \mathrm{h.} .0,8 \mathrm{~m}$ ).

(6 $\mathrm{m} N$ for 2): Haug, nå helt overpløyet. Noermere beskrivelse ikke mulig.

Opplyst ved eieren Johan Schie, Gautestad. 


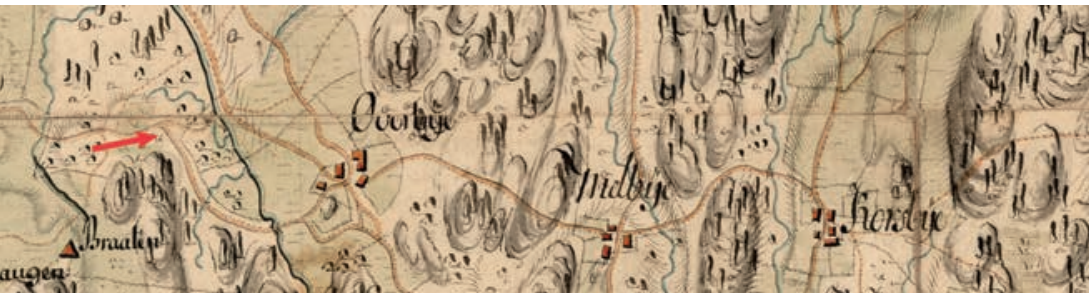

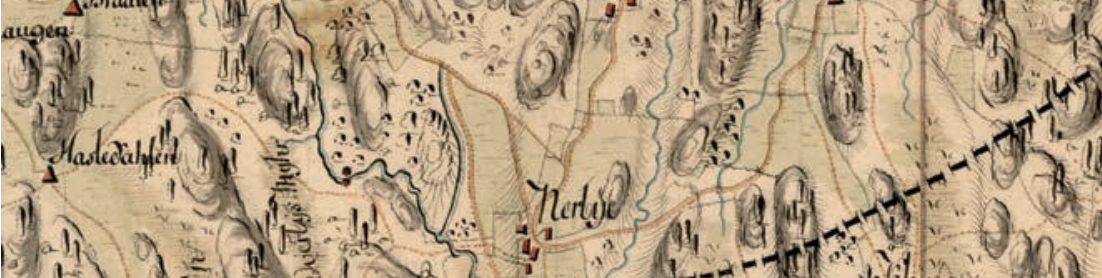

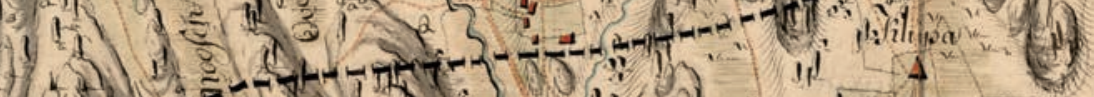

B

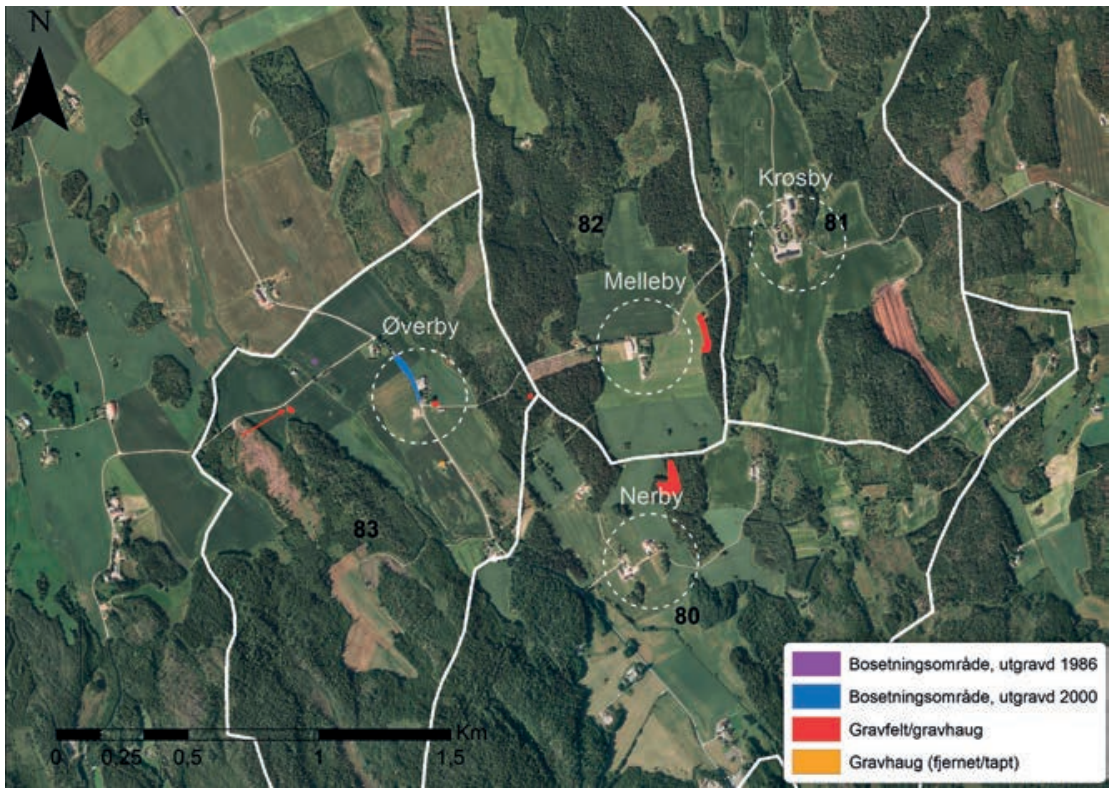

C
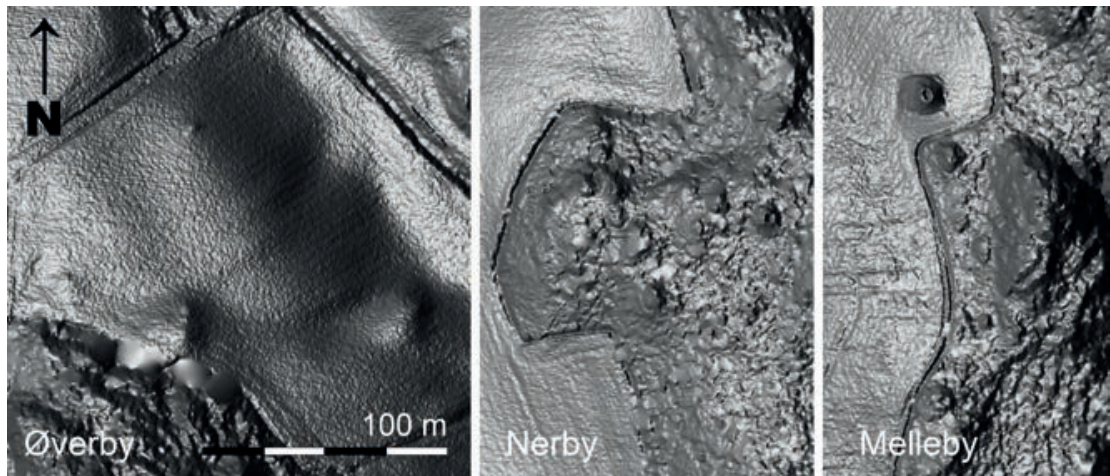
Samlet indikerer gårdsnavnene, de arkeologiske bosetningssporene og gravminnene om en gammel storgård, som muligens kan ha vært setet for vår iril (figur 8).

\section{Diskusjon}

Hva er en iril?

Runologer er enige om at irilaR/erilan er en betegnelse knyttet til eliten (Jakobsen og Moltke 1942:646; Krause og Jankuhn 1966:67; Spurkland 2001:62; Imer 2015 [2007]:63). Imer mener også at relasjonen irilen/erilen blir omtalt i, tyder på at han holdt til i en fyrstes følge. Argumentet hennes er genitivskonstruksjonene (her i oversatt form): Asgisls eril på spydskaftet fra Kragehul, Wiwilas iril omtalt på fjellveggen i Veblungsnes, og Agilamundos iril på steinen fra Rosseland (Imer 2015 [2007]:63). Verken Imer eller andre har viet oppmerksomhet til fordelingen av irilan/erilan-innskriftene i et geografisk, materielt eller kronologisk perspektiv. Det skal vi gjøre i det følgende. Men først skal vi spørre hva ordet egentlig kommer av?

\section{Etymologi}

Forholdet mellom urnordisk nom. irilan og erilan er trolig slik å forstå at irilan er den eldste formen, og at erilas er en yngre variant av denne med $e$ - fra et ikke kjent urnordisk nom. *erlaR. Denne siste formen gjenfinnes i norrønt jarl 'høvding' (med $a$-bortfall ca. 500, $* l_{R}>$ $* l l>-l$ etter $r$ ), mens både irilan og erilaR er gått tapt i norrønt av grunner vi ikke kjenner.

Urnordisk *erlaR er dannet med et suffiks *la- til en germansk størrelse *er-, mens irilaR er dannet til den samme med suffiksvarianten $*_{i l a}$ - (med $*_{e}>i$ ved eldre i-omlyd. Omlyd vil si at rotvokalen er blitt helt eller delvis lik vokalen i den følgende stavelsen). Man har

Figur 8. (A) Oversikt over Øverby og nabogårder i 1795. Sannsynlig plassering av runesteinen er merket med rød pil. Kartet viser også en vintervei langs Øverbybekken $i$ nord og sør (stiplet på begge sider) som også går gjennom tunet til Øverby. På kartet sør for tunet sees også den såkalte Kongehaugen som trolig er en naturformasjon. Utsnitt av Jegerkorpskart-Norge 267, Statens kartverk. (B) Kjente arkeologiske lokaliteter på Øverby og nabogårder. Gårdsgrenser og historiske tun er tegnet inn. Der grensene mellom Øverby, Melleby og Nerby løper sammen, i skogen på sørsiden av Krosbyveien, på sørsiden av Krosbyveien, har det ligget en gravhaug (Askeladden ID 49157) som kanskje har markert grensen i forbindelse med gårdsdelingene. Et større gravfelt med 13 rundhauger og én langhaug ligger i skogen mellom Nerby og Nerbyødegård (Askeladden ID 19562). Enda et gravfelt, med fire runde hauger, ligger i skogkanten på Melleby (Askeladden ID 77747). I utkanten av gamletunet på Øverby ligger en rundhaug (Askeladden ID 10181), og enda en skal ha ligget ca. 250 m lenger sør, men er nå fjernet (Askeladden ID 39582). (C) Mens de plyndrede gravminnene i gravfeltene på Nerby og Melleby er godt synlige på LiDAR-data (flybåren skanner, Light Detection And Ranging), er alle spor etter de fire gravminnene i gravfeltet på Øverby slettet. Strukturene som er synlige der, er uregelmessige i formen og synes å vare natur. Data fra Askeladden. 


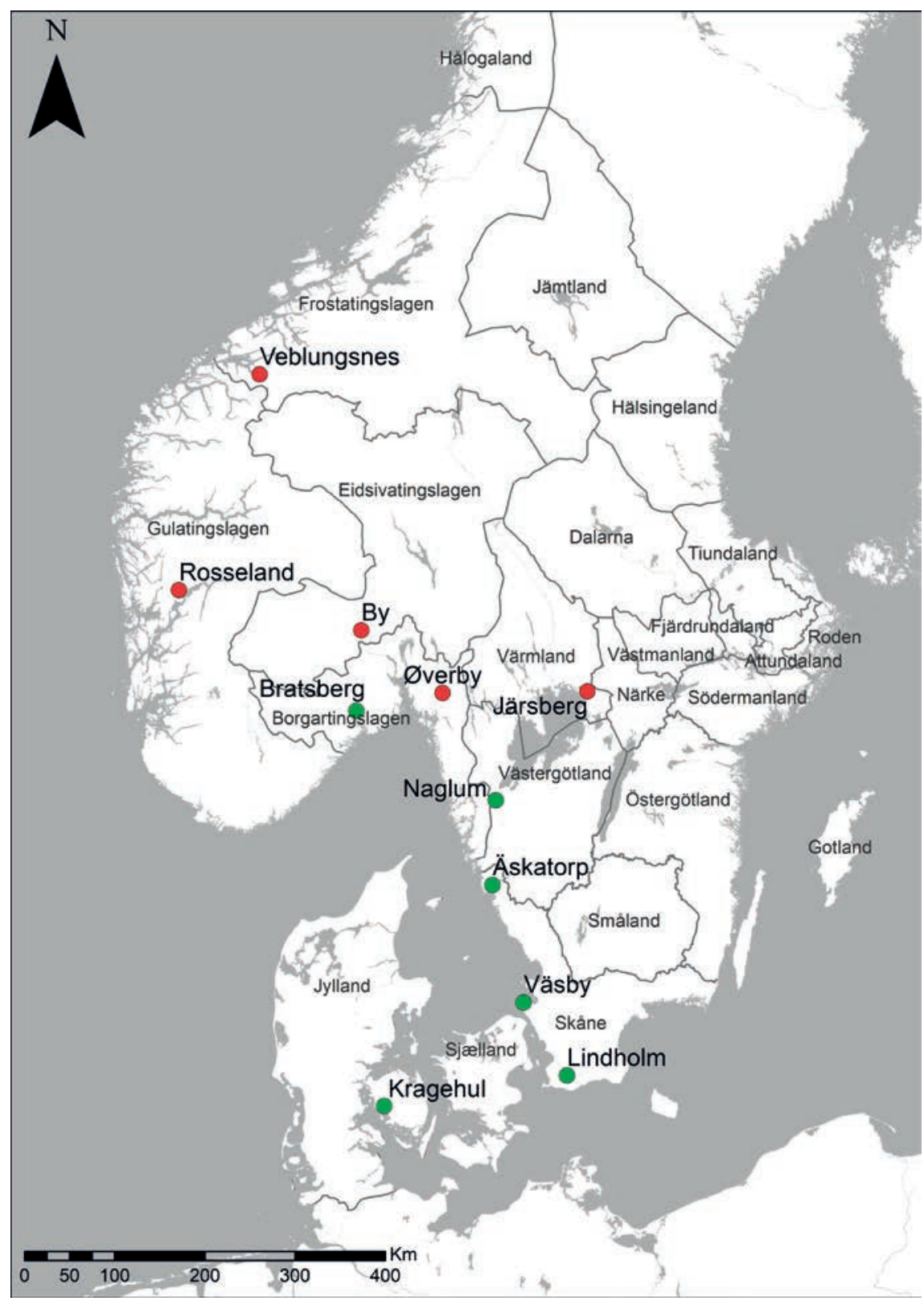

Figur 9 og tabell 1. Alle kjente irilan/erilan-innskrifter plassert på kart (faste innskrifter (rød) og løse (grønn)). By regnes som et fast funn. Lovområdene i Skandinavia er tegnet inn. De faste funnene kan avspeile hvor irilene holdt til, mens innskriftene på de løse funnene kan vare gaver fra irilen (som patron) til klienter. Tabellens data er hentet fra Samnordisk runtäxtdatabas http://www.nordiska.uu.se/forskn/samnord.htm, Krause og Jankuhn 1966, Danske Runer http://runer.ku.dk/og Axboe og Källström 2013. 


\begin{tabular}{|c|c|c|c|c|c|c|c|c|}
\hline $\mathrm{Nr}$ & Sted & Signum & Innskrift & Tolkning & $\begin{array}{l}\text { Datering } \\
\text { (Imer) }\end{array}$ & Objekt & $\begin{array}{l}\text { Orna- } \\
\text { mentikk }\end{array}$ & Kontekst \\
\hline 1 & Veblungsnes & N KJ 56 & $e^{\wedge} k$ irilaz wiwila $\div$ & $\begin{array}{l}\text { Jeg, erilen, } \\
\text { Wiwila }\end{array}$ & $\begin{array}{l}375 / 400- \\
560 / 570\end{array}$ & fjellvegg & & $\begin{array}{l}\text { fjellvegg } \\
\text { ved fjord og } \\
\text { gårds- } \\
\text { grense }\end{array}$ \\
\hline 2 & Rosseland & $\begin{array}{l}\text { N KJ69 U, B } \\
10538\end{array}$ & $\begin{array}{l}\text { ek wagigaz irilaz } \\
\text { agilamudon }\end{array}$ & $\begin{array}{l}\text { Jeg Wagigar, } \\
\text { Agilamundons iril }\end{array}$ & $160-375 / 400$ & $\begin{array}{l}\text { steinmonu- } \\
\text { ment }\end{array}$ & & $\begin{array}{l}\text { gård med } \\
\text { graver }\end{array}$ \\
\hline 3 & By & $\begin{array}{l}\text { N KJ 71, C } \\
3810\end{array}$ & $\begin{array}{l}\mathrm{e}^{\wedge} k \text { irilaz hrozaz } \\
\mathrm{h}^{\wedge} \text { rozez o(r)te pat } \\
\text { azina ut alail(f^u) } \\
\text { dz } \emptyset \text { rmpï }\end{array}$ & $\begin{array}{l}\text { Jeg, irilen, } \\
\text { HrōRar (den } \\
\text { raske), sønn av } \\
\text { HrōRer, lagde } \\
\text { denne steinen for } \\
\text { Ālaif. }\end{array}$ & $\begin{array}{l}375 / 400- \\
560 / 570\end{array}$ & steinhelle & & gravhelle \\
\hline 4 & Bratsberg & $\begin{array}{l}\text { KJ 16, C } \\
26566\end{array}$ & $e^{\wedge} k^{\wedge} \wedge e^{\wedge}$ rila ${ }^{\wedge} z$ & Jeg, erilen & $475-525$ & sølvspenne & & løsfunn \\
\hline 5 & Øverby & & $\begin{array}{l}\text { lu irilar raskar } \\
\text { runor }\end{array}$ & $\begin{array}{l}\text { Hugg runer inn, } \\
\text { raske iril, for Isni }\end{array}$ & $375 / 400-500$ & $\begin{array}{l}\text { stein- } \\
\text { monument }\end{array}$ & & $\begin{array}{l}\text { gård med } \\
\text { graver }\end{array}$ \\
\hline 6 & Järsberg & Vr 1 & 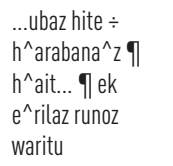 & $\begin{array}{l}\text { Leubar heter jeg, } \\
\text { Ravn blir jeg kalt, } \\
\text { jeg, erilen, } \\
\text { skriver runer. }\end{array}$ & $\begin{array}{l}520 / 530- \\
560 / 570\end{array}$ & $\begin{array}{l}\text { steinmonu- } \\
\text { ment }\end{array}$ & & $\begin{array}{l}\text { steinring- } \\
\text { monument }\end{array}$ \\
\hline 7 & Naglum & IK 639 & $\begin{array}{l}\mathrm{e}^{\wedge} \mathrm{krilaR} \text { : } \\
\text { maripeubar haite : } \\
\text { wraitalap }\end{array}$ & $\begin{array}{l}\text { Jeg, erilen, heter } \\
\text { Maribeubar } \\
\text { (Martjuv). Jeg } \\
\text { skrev"lapo" }\end{array}$ & $\mathbb{E} \in \mathrm{JJ}$ & brakteat & $\begin{array}{l}\text { Hest, } \\
\text { mann, } \\
\text { fugl }\end{array}$ & $\begin{array}{l}\text { overflate- } \\
\text { funn }\end{array}$ \\
\hline 8 & Äskatorp & $\begin{array}{l}\text { KJ 128, IK } \\
241,1\end{array}$ & $\begin{array}{l}\text { f-hidu (u)uilald } \\
\text { uuigaz } e^{\wedge} \text { erilaz }\end{array}$ & Jeg, erilen, malte & $400-650$ & brakteat & $\begin{array}{l}\text { Hest, } \\
\text { flagg, } \\
\text { perler. To } \\
\text { border }\end{array}$ & løsfunn \\
\hline 9 & Väsby & $\begin{array}{l}\text { KJ 128, IK } \\
241,2\end{array}$ & $\begin{array}{l}\text { f-hidu (u)uilald } \\
\text { unigaz e^erilaz }\end{array}$ & Jeg, erilen, malte & $400-650$ & brakteat & $\begin{array}{l}\text { Hest, } \\
\text { flagg, } \\
\text { perler }\end{array}$ & løsfunn \\
\hline 10 & Lindholm & $\begin{array}{l}\text { KJ 29, DR } \\
261\end{array}$ & $\begin{array}{l}\text { a) ek erilaz sa } \\
\text { wilagaz hateka b) } \\
\text { aaaaaaaazzznnn- } \\
\text { bmuttt : alu : }\end{array}$ & $\begin{array}{l}\text { a) Jeg, erilen, } \\
\text { som heter } \\
\text { Wilagar (den } \\
\text { listige) b)......... : } \\
\text { alu : }\end{array}$ & $\begin{array}{l}375 / 400- \\
560 / 570\end{array}$ & beinfragment & & løsfunn \\
\hline 11 & Kragehul & $\begin{array}{l}\text { KJ 27, DR } \\
196 \mathrm{U}\end{array}$ & $\begin{array}{l}\text { ek } e^{\wedge} \text { rila^} z \\
\text { asugisalas } \\
m^{\wedge} u h^{\wedge} a h^{\wedge} \text { aite } \\
g^{\wedge} a^{\wedge} a^{\wedge} a \text { ginu } \\
g^{\wedge} a h^{\wedge} e . . . \text { lija ... } \\
\text { hagala wiju big- ... }\end{array}$ & $\begin{array}{l}\text { Jeg, (er) Åsgisls } \\
\text { eril; (jeg) heter } \\
\text { Muha ... }\end{array}$ & $450-500$ & lanseskaft & & offerfunn \\
\hline
\end{tabular}


gjerne stilt dem sammen med ōn-stammen i norrønt jara f. 'strid, kamp' (< urnordisk *erōn-). Den antatte størrelsen *er- i disse formene bør være en verbalrot, men en germansk rot med en passende betydning kan ikke sikkert påvises.

Det er på den annen side mulig at vi har spor av en germansk verbalrot *ar- 'gå på, stride osv.' i norrønt erjusamr 'nærgående' og nyislandsk erjusamur 'ufredelig, trettekjær' til nyislandsk erjur f. pl. 'stridigheter' < jōn-stammen urnordisk *arjōn- (alle med $e<* a$ ved j-omlyd). Denne roten kan foreligge også i adjektivet norrønt ern 'rask, energisk, kraftig, dyktig' og i nyislandsk ern med verbet færøysk ernast 'kvikke opp' (se f.eks. Blöndal Magnússon 1989:430). Adjektivet kommer etter all sannsynlighet av en i-stamme urnordisk *arni- (med bl.a. *a > e ved i-omlyd) og hører sammen med gotisk adv. arniba 'sikker'. Det kan følgelig analyseres som en dannelse med $n i$-suffiks til roten *ar-, dvs. germansk *ar-ni-.

Germansk *ar- kan stilles til ikke-anatolisk indoeuropeisk *or- 'bevege, drive (fram)' (med $*_{o}>*_{a}$ ) som i siste instans ligger til grunn for gresk órnumai 'jeg rører meg, begynner' og latin orior 'jeg står opp' (se under renne $e^{1}$ og reise 1 i Bjorvand \& Lindeman). Problemet med denne etymologien er at størrelsen *er- i *erlas og irilas i så fall må inneholde et yngre, analogisk germansk $e$-trinn. Det er mulig, og et tilsvarende ungt $e$-trinn foreligger muligens i f.eks. finger (< germansk *fengrá- m.). Semantisk sett er følgelig *erlas og irilaR avgjort positivt ladede dannelser, brukt om menn med pågangsmot og andre gode egenskaper som var nyttige både til strid og fredelige sysler.

\section{Øverbysteinen i lys av andre irilan/erilan-innskrifter}

Den kronologiske spredningen av irilaR/erilan-innskrifter bekrefter langt på vei den språkhistoriske utviklingen der irilaR er representert i innskrifter som er datert til periodene 160 375/400 og 375/400-560/570 (Rosseland N KJ 69; Veblungsnes N KJ 56; By N KJ 71), mens kun én erilaR-innskrift er datert til 375/400-560/570 (beinfragmentet fra Lindholm), de øvrige fra 400-650, 475-525, 450-500, og 520/30-560/570 (Järsberg Vr 1). Særlig kan det legges merke til at innskriften på Järsbergmonumentet, den eneste på stein som inneholder erilan og ikke irilan, er yngre datert.

Videre kommer det frem at fire av fem innskrifter i stein bruker formen irilan, mens samtlige løsfunn bruker formen erilan. Irilan/erilas på steinmonumenter: Det er fem irilaR/ erilan-innskrifter hugget i stein, inkludert Øverbysteinen. Fire av innskriftene ser ut til å ha vært plassert i nærheten av graver (Rosseland N KJ 69 U; By N KJ71 U; Järsberg Vr 1, Øverby NN). Järsbergsteinen har vært del av et større steinringmonument i nærheten av en vei og et gravfelt (Imer 2011), men var tidligere tolket som et monument over en bestemt grav (Jansson 1976). Gravkonteksten som fire av de fem steininnskriftene opptrer i, tyder på at irilen hadde en rolle i gravritualet. Veblungsnesinnskriften skiller seg ut, da den er funnet på en fjellvegg ut mot havet ved matrikkelgårdsgrensen for gården Veblungsnes, og kanskje kan tolkes som en territoriell markør.

ErilaR-innskrifter på løsfunn og våpen: Det er i alt seks innskrifter på smykker og våpen som inneholder ordet erilas. Det gjelder et beinfragment, tre brakteater og to spenner. Funnkontekstene for løsfunnene peker verken i retning av bosetninger eller deponeringer, men snarere mot graver som er blitt skadet av jordbruksaktivitet. Løsfunnene kan ha vært gaver før de ble lagt i en grav, og antyder ikke nødvendigvis at erilen kommer fra det samme området som der innskriften er funnet. Alle erilaR-innskriftene på løsfunn er datert innenfor 


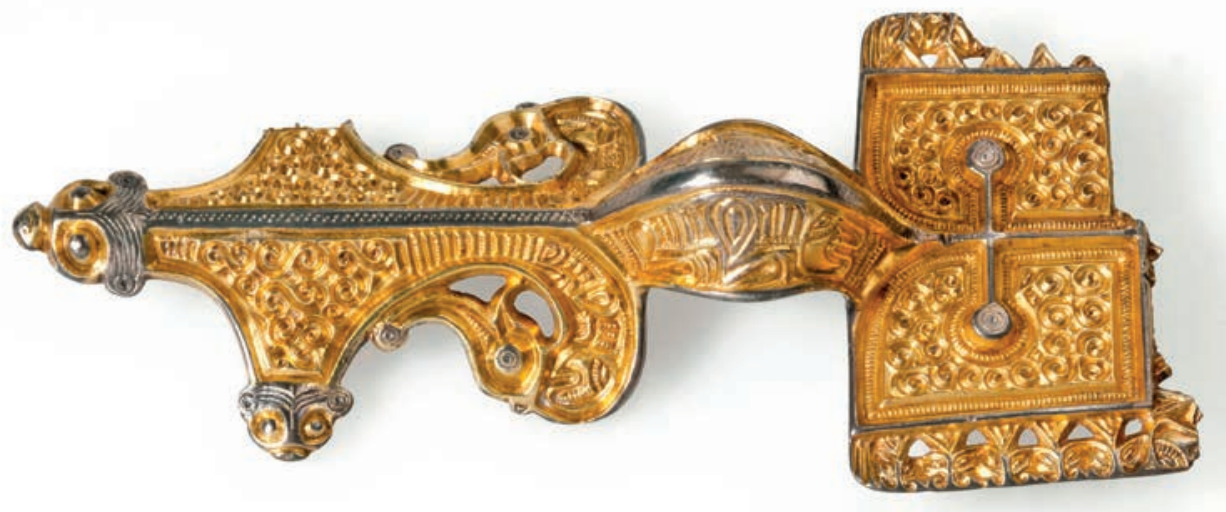

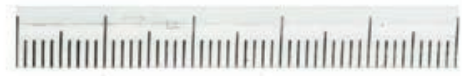

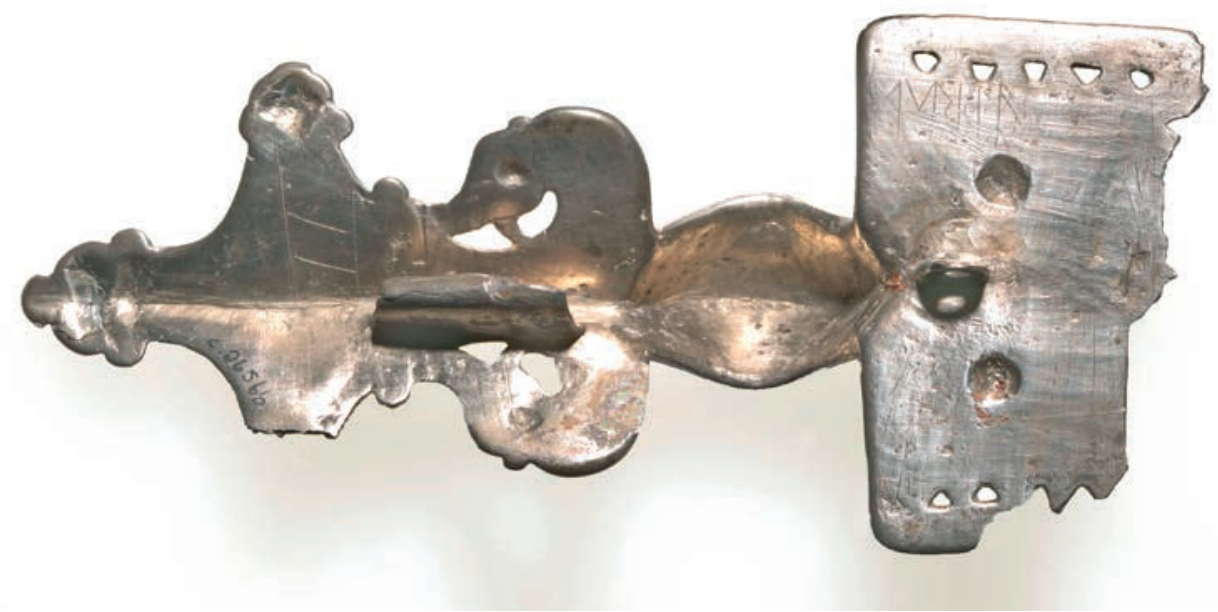

Figur 10. ek erilan, 'jeg erilen', står det på baksiden av Bratsbergspenna, Skien, Telemark, datert til 475-525. Spenna er funnet på parsellen Solhaug av storgården Bratsberg, Gjerpen sogn og prestegjeld, Telemark. Bratsberg var i middelalderen det sentrale maktsenteret $i$ Grenland og var blant annet setegård for de mektige lendmennene Dag Eilivsson (slutten av 1000-tallet - begynnelsen av 1100-tallet) og Gregorius Dagsson (d. 1161). Spenna var slitt da den trolig ble nedlagt som et gammelt arvestykke i en yngre grav, kanskje i merovingertid eller begynnelsen av vikingtiden. Foto: Kulturhistorisk museum, Mårten Teigen (forside) og Eirik Irgens Johnsen (bakside). 
tidsperioden 375-400 til 600 (etter Imer 2015 [2007]). Tre brakteater har erilan-innskrift. Brakteatene skriver seg inn i en stor gjenstandsgruppe med masseproduserte gullanheng fra folkevandringstid og merovingertid som ofte er funnet i mannsgraver, kvinnegraver, i hus og som løsfunn (se Nowak 2003:253-260 for gjennomgang av brakteater med erilaRinnskrifter).

Verken brakteaten fra Väsby (KJ 128, IK 241,2) eller Äskatorp (KJ 128, IK 241,1) kan knyttes til bestemte kjønnsdefinerte graver. Begge brakteatene består av et ikonografisk midtmotiv som forestiller en venstrestilt hest med et mulig flagg og en «perle»-formasjon over ryggen. Midtmotivet er omkranset av et runebånd. Både motiv og runebånd er stemplet. De to brakteatenes stempelmønster er identisk. Äskatorp-brakteaten har imidlertid ytterligere to rader med ornamentiske border på utsiden av stempelmønstret, og er nesten $2 \mathrm{~cm}$ bredere. Det ikonografiske motivet kan kanskje tolkes som en militær formasjon, og smykket kan avspeile en militær struktur; det kunne være en gave fra en herre til en undersått. Kanskje uttrykker de to brakteatene en forskjell i rang. En liknende funksjon kan foreslås for brakteaten fra Trollhättan II (Axboe og Källström 2013). Brakteaten er funnet i fyllmasser syd for et sluseområde ved Trollhättan. Det ikonografiske motivet består av et hesteliknende dyr med et mannshode tett liggende over dyrets nakke. Mannens hårstreker ender i et fuglehode. Runeinnskriften omkranser motivet.

Bratsbergspenna (KJ 16, C 26566) fra Telemark i Norge (Hougen og Olsen 1937) er knyttet til en rikt utstyrt kvinnegrav som indikerer en kvinne med høy sosial status (figur 10) (Røstad 2019 med ref.). Innskriften ek erilar, som forekommer på objektets bakside, kan tjene som en forklaring av kvinnens høye status - kanskje er hun erilens kone eller datter. Spenna har gått i arv i flere generasjoner før den på et tidspunkt fikk følge med i graven til personen som eide den (Røstad 2019:80-88).

Innskriftene på brakteatene og spennene kan indikere at erilen er giveren av smykket. Bratsbergspennas innskrift kan tolkes som giverens «signatur» for å markere relasjonen til mottakeren, som i dette tilfelle kan dreie seg om en kone. Innskriften på de masseproduserte brakteatene (når det finnes to stempelidentiske brakteater, har det sirkulert mange flere) kan tyde på at erilen har gitt brakteatene til sine undersåtter som en bekreftelse på deres tilhørighet til ham. Det er flere usikre erilan-innskrifter på smykker og brakteater: G 98 U, G 45, G $85 \mathrm{mfl}$. Dersom de inneholder ordet erilaR, kan innskriftene og objektene trolig tolkes på samme måte som de øvrige smykkene: som en markering av relasjoner.

På et offersted i Kragehul sør på Fyn i Danmark er det funnet fem deponeringer av militært utstyr fra perioden 200 til 475. Et lanseskaft med en erilar-innskrift (DR 196 U) tilhører trolig den seneste ofringen. I innskriften fremkommer det at erilen har en høyerestående herre: Åsgisl. Konteksten taler for et militært anliggende. Fra eldre jernalder i Danmark finnes det mange offerfunn som er forstått som seier- eller takkoffer etter krigføring. Dersom lanseskaftet fra Kragehul kan forstås i en tilsvarende kontekst, har Muha, erilen til Åsgisl, vært del av den tapende part i en kamp, og hans våpen ble del av motstanderens takkoffer etter kamphandlingen. Åsgisl kan ha vært en konge og Muha hans undersått.

Et annet våpen, en spydspiss, med en mulig erilar-innskrift er funnet i Rozwadów i Polen (KJ 35). På den sier ikke innskriften eventuelt mer enn «jeg, erilen» eller «jeg, jarlen» (se Garbazc 2016). I likhet med de usikre brakteat- og smykkeinnskriftene er denne innskriften også usikker. Hvis den skulle være en erilar-innskrift, kan den i likhet med Kragehul-spydskaftet, vise til erilens militære tilknytning. 
Beinfragmentet fra Lindholm (KJ 29, DR 261) skiller seg ut fra de øvrige løsfunnene ved å ha en lengre innskrift som foruten beskrivelsen av erilen og hans navn/kallenavn, inneholder åtte a-runer, tre R-runer, to (sannsynligvis tre) $\mathbf{n}$-runer, $\mathbf{b}, \mathbf{e}, \mathbf{u}$, tre t-runer og til sist, etter et interpunksjonstegn, formelordet alu. Gjenstanden er blitt tolket som en amulett, og de gjentatte runetegnene har vært ansett som formler innrisset med en intensjon om beskyttelse. Helt nøyaktig kan vi ikke vite hva innskriften betyr, men kanskje ligger det en mening bak. Det er ikke umulig at linjene 2 og 3 på Øverbysteinen inneholder tegn og formler med en gitt intensjon.

Ordet $r \bar{u} n \bar{o} R$ er akk. pl. av ordet for 'rune', som i urnordisk tid kan ha hatt betydningen 'hemmelig budskap' snarere enn den yngre betydningen 'runetegn'. Denne abstrakte betydningen til ordet $r \bar{u} n \bar{R}$ gjenfinnes i got. rüna 'hemmelighet', gs., ght. rūna, mht. rūne, geng. rūn 'fortrolig og hemmelig samtale, hemmelighet' osv., videre ght., gs. girūni, geng. gerȳne n. 'hemmelighet' og got. garüni n. 'rådslagning' < germ. * ga-rūnija-(Bjorvand \& Lindeman 2019:980). Et slikt «hemmelig budskap» kan passe med f.eks. hvordan militær kommunikasjon kan ha foregått mellom kongene og irilene i forskjellige landskap.

Verbet faihidō, som opptrer i relasjon til erilen på Väsby og Äskatorp-brakteatene, indikerer subjektets - erilens - handling, nemlig å male / å skrive. Denne innskriften (som er identisk på disse to brakteatene) inneholder ikke ordet rūnōR. Det er trolig at verbet viser til produksjonen av brakteaten, og verbet kan strengt talt vise til både ornamentikken og innskriften i runebåndet. I alt er det 4 av de 11 irilan/erilan-innskriftene som inkluderer et verb som viser at irilen/erilen har hatt en rolle i produksjonen av objektene med runeinnskrifter; warītu, 'jeg skriver' opptrer på Järsbergmonumentet, faihidō 'malte' opptrer på Väsby og Äskatorp-brakteatene. Det viser at det er en variasjon i verbalbruken på disse innskriftene, og det gjør verbet lū i betydningen 'hugg!' til et plausibelt tilskudd av verb til irilaR/erilarinnskriftene. Verbene som opptrer i innskriftene, opptrer helst i fortidsform: de gjorde, skrev eller malte runer (og ornamentikk?). Imperativformen $l \bar{u}$ ! på Øverbysteinen, som oppfordrer irilen til å hugge runer, er derfor iøynefallende, men viser, som de andre, til produksjonen av innskriften. Trolig vises det til runer i betydningen 'hemmelig budskap' eller 'fortrolig samtale'. Hva budskapet skulle ha vært, er ukjent på grunn av den skadede B-siden. Men i og med at monumentet ser ut til å være knyttet til et gravfelt, og kanskje til og med til en kvinnegrav, kan det være en mulighet at irilen har risset inn et budskap forbundet med den avdøde.

I gjennomgangen av objektkategorier og kontekster trer noen av irilens roller frem. Monumentene var plassert ved samlingssteder og ferdselsårer. Flere av dem opptrer i gravkontekster og antyder at irilen deltok i gravritualer. Det betyr ikke nødvendigvis at han var kultleder. Løsfunnene på smykker og amuletter viser erilens funksjon som produsent og giver. Han markerer sine relasjoner til undersåtter og til kvinner - trolig koner. Genitivsformene som opptrer på Kragehul, Rosseland, og muligens Veblungsnes, indikerer at irilen/ erilen inngikk i en hierarkisk struktur. Våpenfunnet peker mot at erilen hadde en militær funksjon. Beinfragmentet fra Lindholm kan antyde at han hadde kunnskap om magiske formularer, og en eventuell kultisk rolle, slik det også blir foreslått for Trollhättan-erilen (Axboe og Källström 2013).

De egennavnene og/eller tilnavnene som er satt til ham i innskriftene, kan muligens si noe om hvilke egenskaper som karakteriserte irilen/erilen: Maripeubar,i betydningen 'Martjuv' (havstyv) eller Māripeubar i betydningen 'Märtjuv' (berømt tyv) på brakteaten 
fra Trollhättan. Sa Wīlagar, som kan bety ‘den listige’ (Krause og Jankuhn 1966:69), opptrer på Lindholm-beinfragmentet, LeubaR 'behagelig' og HarabanaR 'ravn' opptrer på Järsberg, samt HrōRaR med betydningen 'kvikk/rask’ på Bysteinen, og til sist raskaR (Øverby) trolig i betydningen 'dyktig'. En iril/eril var altså kvikk, rask, dyktig, listig, og én av dem sammenliknes med en ravn. Tilnavnene indikerer at irilen/erilen var en vital person i sin beste alder. Vi har allerede hørt at termen irilan var positivt ladet.

\section{irilar/erilan i lys av politiske, sosiale og geografiske forhold}

Arkeologer, historikere og filologer har diskutert samfunnsorganisasjonen i eldre jernalder med grunnlag i ulike kilder. Arkeologer har tatt utgangspunkt i rike funn, store gravminner og bygdeborger for å identifisere datidens maktsentre; historikere og filologer har tatt utgangspunkt i klassiske forfattere og kilder som nevner forhold i Skandinavia, slik som Tacitus, den gotiske historikeren Jordanes (500-tallet) og den østromerske historikeren Prokopius (ca. 500-565), navn på steder og folkegrupper, samt runeinnskrifter (Brink 2007; Andersson 2009). Blant de mest toneangivende arkeologiske studiene finner vi i Bjørn Myhres (1987) arbeid, ikke minst hans siste verk om nettopp Viken, der Borre trer frem som et politisk maktsenter på 600-tallet (Myhre 2015).

Det er få skriftlige kilder til politisk og militær organisering i Skandinavia i romertid og folkevandringstid (200-575), og felles for kildene er at de ofte er forfattet av romere og grekere uten førstehåndskunnskap om Skandinavia. En vanlig oppfatning er at disse forfatterne hadde tilgang til informanter med særskilt kunnskap om Skandinavia. Lotte Hedeager merker seg særlig en Roduulf rex som er navngitt i Jordanes' De origine actibusque Getarum, den såkalte Getica fra 551 (Hedeager og Tvarnø 2001). Den aktuelle passasjen (Getica 24) omtaler Rodulf som konge over grannii, grener (Grenland); augandzi, egder (Agder); eunixi (Lista?); tatel rugi, adelryger (Rogaland); arochi, horder (Hordaland); og noe mer usikkert ranii, raumer (Romsdal) (Svennung 1967; Hedeager og Tvarnø 2001; Iversen 2019).

Rodulf var antakelig en landflyktig konge som kan ha rådd over større eller mindre deler av Vestlandet (Krag 2003:58). Andre kilder omtaler Rodulf som konge over erulene, en gruppe som visstnok slo seg ned i Pannonia (nåværende Ungarn), der de ble fordrevet i 508, da Rodulf også døde. Dersom det dreier seg om den samme Rodulf (Skre 1998:256-7), gjorde han kan hende karriere hos erulene etter å ha rømt Vestlandet, slik Lotte Hedeager tenker seg (Hedeager og Tvarnø 2001:271). Utbredelsen av irilar-innskriftene sammenfaller delvis med området som Rodulf kanskje var konge over.

Det er interessant at det finnes én irilaR-innskrift i hvert av de yngre lovområdene Frostatingslagen (Veblungsnes), Gulatingslagen (Rosseland), Eidsivatingslagen (By), Borgartingslagen (Øverby) og Värmland (Järsberg) (figur 9 og tabell 1). Stedene der innskriftene forekommer, ligger ved viktige kommunikasjonsruter i utkanten av eldre fylker. Veblungsnes ligger meget strategisk innerst i fjordsystemet i Romsdal fylke, der hovedferdselsåren opp Romsdalen fører til Gudbrandsdalen i Eidsivatingslagen. Veblungsnes lå i Romsdal åtting, lengst sør i fylket der all ferdsel øst-vest passerte. Også Rosseland (norr. hross n., hest - «hesteland») i Steinsdalen i Øystese skipreide, lengst nordvest i Hardanger, lå strategisk til med oversyn over hovedveien til og fra Voss og Nordhordland, og nær Hardangerfjorden og grensen til Sunnhordland. En mer sentral plassering med tanke på kommunikasjon mellom de gamle fjerdingene i Hordaland kan knapt tenkes (figur 11). 

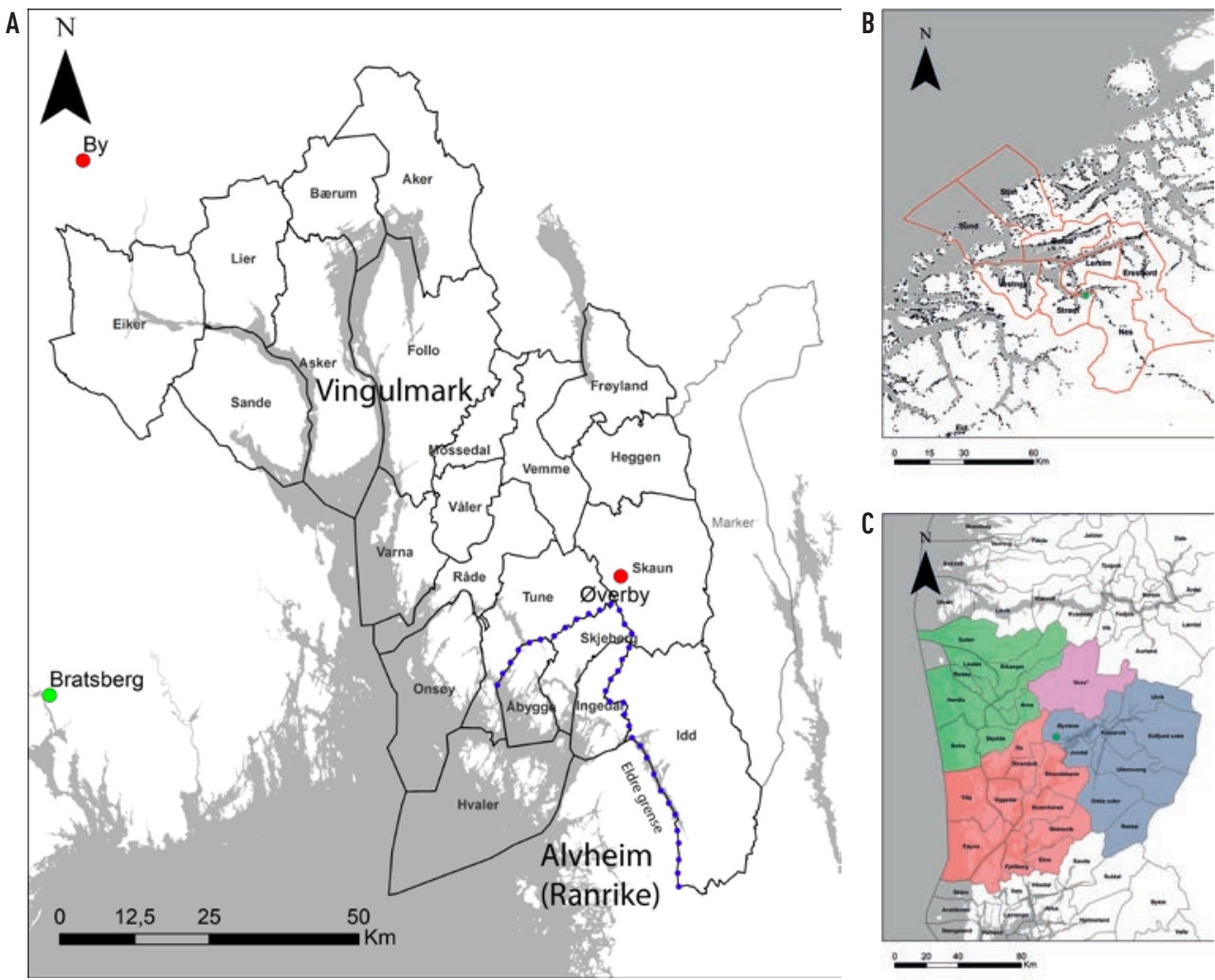

Figur 11. (A) Historisk inndeling av fylket Vingulmark. Øverby lå øst i fylket i Skaun skipreide mens Markerbygdene lengst øst kan ha ligget under Sveakongen $i$ vikingtid. Følger vi Snorre, må Ảbygge og Skjeberg ha ligget i Alvheim i vikingtid - landet mellom Glomma og Göta älv. Kanskje var Alvheim identisk med Ranrike i jernalderen. Søndre del av Ingedal (Enningdalen sogn) lå under Ranrike provsti i middelalderen. Det ser slik ut til at irilen holdt til $i$ et grenseområde. (B) Rosselandssteinen (markert grønt) i nåvaerende Hordaland lå $i$ Øystese $i$ Hardanger noer grensen til det eldre Horda fylket (Nordhordland og Sunnhordland) og dessuten Voss fylke. (C) De historiske åttingene i Romsdal fylke. Veblungsnesinnskriften (markert grønt) lå $i$ Strøm åtting (også kalt Romsdal åtting) ved foten av den viktige Romsdalen, innfartsåren fra sør-øst. Svarte prikker på kartet viser historiske tun.

Dersom Sunnhordland og Nordhordland opprinnelig dannet et fylke (Hordaland), og Hardanger og Voss var egne fylker, lå Rosseland sentralt der fylkene møttes. By lå midt $\mathrm{i}$ Sigdal, og hadde en liknende plassering ved ferdselsårer nord-sør og øst-vest. Sigdal var det vestre dalføre i et nå forsvunnet fylke (partia) omtalt i Historia Norwegie (ca. 1150-75), som trolig besto av Tverrdalene (Modum, Krødsherad og Sigdal), Ringerike, Romerike og Hadeland med Toten (Iversen 2017). I vest grenset Sigdal mot Numedal, som sammen med Øvre Telemark dannet et fylke (patria), og mot sør ved Åmot grenset Sigdal til Eiker, som 
lå nordvest i Vingulmark. Dermed lå også By nær grensen for tre fylker. Også Järsberg, lengst øst i Värmland, ligger ved viktige ferdselsårer øst-vest og nord-sør, i overgangen mellom sjø (Vänern) og land, nær grensen mot Närke som historisk var knyttet til svearne. En slik plassering synes også å gjelde for Øverbysteinen. Gården Øverby lå i Utanskog fjerding av Skaun skipreide (Rakkestad) i middelalderens Vingulmark. Markerbygdene i øst lå under sveakongen i vikingtid, og kanskje før (Hkr, Magnus Berrføtts saga kap. 12; Ødegaard 2015:147). Leidangordningen fikk ikke feste i Marker (Steinnes 1929:53), som sannsynligvis ikke var en del av Vingulmark i eldre tid. Vingulmarks vestgrense kan ha gått ved Skjeberg mot det omdiskuterte «Alvheim» - et gammelt navn på landet mellom Raumelfar (Glomma) og Gautelfar (Göta älv) (Hkr, Ynglinga saga kap. 48). Meningene omkring Alvheim har variert blant historikere. Lengst gikk Asgaut Steinnes. Han avviste Alvheim som et landskapsnavn og anså det som et kongesete: Alvim i Tune (Steinnes 1950).

P. A. Munch mente at grensen mellom Vingulmark og Alvheim skulle søkes ved nedre Glomma og videre ved «... de høydestrekninger, der adskille Rakkestad fra Skjeberg ...» (Munch 1849:160). Det var først da Ranrike og Vingulmark ble delt i sysler på 1000-tallet at Borgarsyssels sørgrense ble satt ved Svinesund. Dersom Munch har rett, lå Øverby faktisk direkte ved en eldre fylkesgrense i vikingtid og kanskje før. Utanskog og Skaun lå etter alt å dømme i utkanten av Vingulmark da runesteinen ble til. Vi ser et liknende mønster for løsfunnene som ikke kan tillegges samme vekt. De to brakteatene fra Naglum (Västergötland) og Äskatorp (Halland) er begge funnet i grenseområder. Dette er ikke så tydelig for funnene fra Bratsberg (Grenland), Väsby (Skåne) og Danmark (Fyn). Det kan bety at irilen hadde funksjoner knyttet til grenser og kommunikasjon på tvers av fylker og lovområder, og det understøtter en militær funksjon.

Den svenske lingvisten Alvar Ellegård (1987) har gått igjennom alle kildene til erulene som har vært koblet til irilan-innskriftene, først diskutert av Sophus Bugge (1891). Ellegård, og før ham både P.A. Munch (1852:53) og Fridtjof Nansen (1911:146) mente at erulene var en sør-europeisk betegnelse for et forbund av krigere fra nord. Ved én anledning, i 545, skal utsendinger fra erulene ha reist til Thoule for å finne seg en ny konge. Denne personen måtte være av kongelig slekt, og det fantes mange slike der. Førstevalget deres døde ved danenes land, og de returnerte til Thoule. De fant da frem til en Datius, som etterhvert ble deres konge på Kontinentet, og som fikk følge fra Thoule av sin bror Aordus og 200 unge eruler. Prokopius opplyser at erulene i Thoule, som han omtaler som «de innkomne», var bosatt ved siden av Gautoi (dvs. gøtene) - som han skriver var en av de største gruppene på Thoule.

Opplysningen om at erulene bodde ved siden av gøtene, er unektelig interessant. Det er påfallende at de fem faste irilar-innskriftene nettopp finnes i områdene nordvest for gøtene. Det er likevel høyst usikkert, og lite sannsynlig, at det er en direkte sammenheng mellom krigergruppen eruler og irilan-innskriftene, selv om det ikke kan avvises hundre prosent på etymologisk grunnlag. Ellegård, som er autoriteten innen «erul-forskningen», har derimot en annen forklaring. Han hevder, med troverdig kildegrunnlag, at erulene på Kontinentet ble delt på begynnelsen av 500-tallet, og at den ene gruppen migrerte til Skandinavia omkring 512 og slo seg ned i nærheten av gøtene (Ellegård 1987:11). Det var fra denne gruppen de andre erulene en drøy generasjon senere rekrutterte sin nye konge. Ellegårds teori fremstår som et friskt alternativ til de tradisjonelle teoriene som argumenterer for at 
erulene hadde et opprinnelig opphav (Stamsitz) i Norge eller Sverige. En kombinasjon av disse teoriene er heller ingen umulighet.

\section{Jarl i en urolig tid?}

Romertid og folkevandringstid var en urolig periode i Skandinavia, slik f.eks. nye funn fra ringborgen Sandby borg på Öland vitner om, der en massakre av borgens forsvarere fant sted mot slutten av 400-tallet. Drepte og dyr som sultet i hjel, ble liggende urørt frem til de arkeologiske utgravningene startet i 2011. Bare $6 \%$ av borgen er utgravd per 2018 (ca. $300 \mathrm{~m}^{2}$ ), og foreløpig er det funnet spor etter 26 drepte, flest menn og noen barn, men ingen kvinner, i det som kan dreie seg om krigshandlinger der flere hundre ble drept og kvinner kanskje kidnappet (Alfsdotter et al. 2018).

Danske våpenofferfunn, som blant annet inneholdt én irilar-innskrift (Kragehul), kan kaste lys over Øverbysteinens innskrift. Det har vært foreslått at krigerne som ble beseiret og ofret i Illerup på Jylland i Danmark, kom fra dagens Sør-Norge og Vest-Sverige (Ilkjær 1993 fig. 153, 2001, 348; Carnap-Bornheim og Ilkjær 1996, 296-298), det vil si hovedområdet for de faste irilaR-innskriftene. Én av deponeringene (Illerup A) fra omkring år 200 er blitt studert inngående. Omkring $40 \%$ av lokaliteten Illerup A er blitt arkeologisk undersøkt, og har blant annet gitt funn av 410 spydspisser og skjoldbuler som indikerer tre nivåer militær rang. Man har ment at den nedkjempede hæren kan ha omfattet opptil 1200 personer (Carnap-Borheim 1997; Ilkjær 2000:144), og det er foreslått at det dreier seg om en hær fra Sørvest-Norge som ble beseiret av en jysk hær (Grimm og Stylegar 2004).

I 2014 ble det foretatt nye strontiumisotopanalyser av tenner fra to av de fire store krigshestene (ca. 130-141 cm i mankehøyde) i Illerup-funnet. Strontiumverdiene lå omkring 710, som er typiske for Jylland, Sjælland og Skåne, men som også forekommer i nettopp Viken (Dobat mfl. 2014:202). Forutsetter vi at de eldre proveniensanalysene er riktige, og at godt trente krigshester var noe man tok med seg, er Viken forenlig med tidligere forslag til hærens opphav, basert på gjenstandsstudier. Men forfatterne peker på at hestene like gjerne kan ha vært lokale (f.eks. fra Jylland), og at de var i live inntil de ble ofret. Spørsmålet er om irilaR-innskriftene kan knyttes direkte til militære spesialister som var med i slike slag? Kanskje hadde irilen også ansvar for militært hestehold? Det indikeres av navnet Rosseland og brakteatene som har hesteikonografi kombinert med erilaR-innskrifter.

Det finnes ingen irilar/erilar-innskrifter med yngre datering enn 450-600. Betegnelsen synes altså å forsvinne helt i overgangsperioden fra eldre til yngre jernalder og opp mot norrøn tid. Det er imidlertid ikke bare irilen/erilen som forsvinner i denne perioden, det er et helt samfunn som forsvinner. Bygdeborgene går av bruk, kokegropfeltene avtar og forsvinner, antall graver reduseres med 70-90\%, et stort antall ødegårder kan påvises, smykketyper og draktutstyr endres, og språket gjennomgår store endringer på vei fra urnordisk til norrønt. Skriftsystemet endres gradvis fra en 24-tegns futhark til en 16-tegns futhark. Nyere forskning viser et samfunn preget av demografisk krise som følge av pest (ca. 541-750) og klimaendring og nedkjøling (den såkalte Late Antique Little Ice Age, «LALIA», ca. 536660) (Iversen 2016). Et samfunn med drastisk befolkningsnedgang mister de administrative funksjonene, og det er først når samfunnet bygges opp igjen, at en ny organisering av administrative roller trer frem. Betegnelsen erilas dukker ikke opp igjen i yngre materiale, men termen jarl og termen skáld dukker opp i skaldediktene fra 900-tallet (for eksempel Háley- 
gjatal og Vellekla). Skáld er nevnt på fem runesteiner uten at innskriften var kvad (Jesch 2008:6). Jarl er også nevnt på to-tre runesteiner i Uppland og Småland («Håkon jarl-runesteinene») (U16, U167 og Sm76). Det kan dreie seg om ulike jarler, men det har vært vanlig å identifisere dem med Håkon Eriksson, ladejarl (død 1029) (Wessén og Jansson 194043:24-26). Hans far, jarl Eirik Håkonsson (ca. 964-1024), ble forlent Vingulmark og Romerike av danekongen Harald Gormsson på slutten av 900-tallet, og fikk disse områdene på samme vilkår som skattekongene før ham (Hkr, Olav Tryggvasons saga, kap. 20). Eyjolf Dådaskald, ladejarlens hirdskald, omtaler vasallforholdet i Bandadrápa (str. 3). Skalden benytter ikke navnet Vingulmark eller Romerike, men en kjenning: Yggjar brúði, «Odins hustru». Snorre har forstått dette som Vingulmark og Romerike, og har kanskje koblet konkret geografi og kjenning med utgangspunkt i en kjent tradisjon. Det forlente landet symboliseres med hustruen, og jarlen med Odin, kanskje særlig hans krigerske kvaliteter.

Et sjeldent eksempel på en gammel jarleslekt fra vårt område finnes i Landnámabók (slutten av 1100-tallet) og Gautreks saga (slutten av 1200-tallet). Der omtales landnåmsmannen Orm gamle. Han var sønn av Eyvind jarl som hadde kjempet mot Harald Hårfagre i Hafrsfjord og tapt sin politiske posisjon. Eyvind jarl var sønn av Armod jarl, sønn av Nerid jarl den gamle og nidske (egoistisk, gjerrig, smålig), også kalt den rådspake (rådkloke). Historikeren P.A. Munch (1852:342, note 5 og 1853:517-522, note 4) mener at det spesielle navnet Nerid klart peker mot at denne jarleslekten kom fra Grenland eller Øvre Telemark. Hele 11 av 13 kjente forekomster av navnet Nerid i middelalderdiplomer i Norge kommer derfra, og de to siste fra Vestfold. Ikke bare viser denne genealogien at jarletittelen gikk i arv fra far til sønn, men også at vi er på sporet av et jarledynasti i Grenland eller omegn tilbake til omkring 800, da Nerid levde. Selv om man neppe vil få et sikkert svar, kan man spekulere på om Nerid jarl den rådkloke var i slekt med erilen som har etterlatt sin signatur på den 250 til 300 år eldre Bratsbergspenna, som nettopp kommer fra det gamle maktsenteret Bratsberg i Grenland. Spenna var gammel da den ble nedlagt i en grav, og like ved spenna er det identifisert en flatmarksgrav fra vikingtid (Hougen og Olsen 1937:54). Vi nærmer oss da tiden som Nerid jarl levde i. Vi vet imidlertid ikke om den gjerrige Nerid og jarleslekten hadde sete på Bratsberg. Kanskje er dette eksempelet med på å styrke ideen om at det norrøne begrepet jarl må stå i sammenheng med de urnordiske irilar/erilar, selv om det språkhistorisk sett ikke er en ren utviklingslinje mellom dem.

Terje Spurkland har tidligere ment at hvis betegnelsen irilan/erilan skal tilsvare det norrøne ordet jarl, må det ha innebåret at rollen ble sekularisert ved overgangen til norrøn tid (Spurkland 2001:61) - altså i bruksovergangen fra urnordisk erilaR til norrønt jarl. I de eldste kildene til termen jarl argumenterer skalden for jarlens mytiske opphav. For øvrig assosieres jarlen med krig, rettferdighet og som folkets venn. Begrepet skáld er forbundet med ordkunst, men ikke bare det, skalden var også kongens betrodde mann.

Beslutningen om å bruke militær makt kan ha blitt flyttet fra fylkesnivå til overregionalt nivå på 600-700-tallet. I Vest-Norge og i Nord-Norge har dette vært satt i sammenheng med nedleggelsene av ringtunene (Storli 2010; Iversen 2019). I Trøndelag ble de ikke nedlagt før tidlig på 1000-tallet, trolig i forbindelse med at kongen overtok det direkte styret over jarledømmet i 1015. På Østlandet har vi ingen kilder som forteller om denne utviklingen, da hovedtingene der trolig var knyttet til de store kokegropfeltene som synes å ha gått av bruk på 600-tallet, da også det antatte kongelige maktsenteret på Borre etableres. 
Vi mener det må finnes en utvikling i rollen irilaR/erilas som kan gjenfinnes i rollene jarl og skáld i yngre jernalder. Da samfunnet vokste frem igjen etter pest og nedgangstider på 500-tallet, ble nye administrative og militære roller etablert med spor av eldre systemer. Kongen hadde betrodde menn i regionene som var politiske og militære ledere. Korpuset med irilaR/erilaR-innskrifter viser en interessant geografisk spredning, som kan indikere at det fantes iriler i ulike områder. La oss se nærmere på hvilket område irilen på Øverby administrerte.

\section{Irilen på Øverby - hvilket område administrerte han?}

Omkring 1150 besto Norges kystland av fire hovedområder: Viken i øst (Sinius orientalis), Gulatingslagen (Gulacia), Trondheimen (Trondemia) og Hålogaland (Halogia). Dette svarer til Borgartingslag, Gulatingslag, Trøndelag og Hålogaland. Viken besto av fire fylker: Ranrike, Vingulmark, Vestfold og Grenland. Både Ranrike (Ragnaricii) og Grenene (Grannii) er omtalt av Jordanes i 551, mens Vestfold dukker opp i skriftlige kilder i 813 og Vingulmark enda senere. Det er likevel grunn til å anta at disse inndelingene er langt eldre enn tidspunktet da de er dokumentert (figur 5).

Vurdert etter utbredelsen av gravminner i Norge og Sverige hadde Viken en betydelig befolkning i jernalderen med særlig konsentrasjoner sør i dagens Båhuslän, Østfold og Vestfold (Iversen 2019). I vikingtid og tidlig middelalder var Viken et omstridt landområde i klem mellom gryende politiske enheter: Norge, Danmark og Sverige. Så sent som i 1170 ble Erling Ormsson Skakke fra Etne i Sunnhordland jarl i Viken mot å akseptere danskekongen som sin overherre. Som jarl fikk Erling det direkte styret over Viken, og hadde militær tjenesteplikt som motytelse for danskekongen.

Gulatingsloven (ca. 1150) bruker termen Vikverir om folk i Viken (=Vingulmark, Vestfold og Ranrike) og Grónir om folk i Grenland (G 315). Jordanes nevner hverken folkene i Vingulmark eller Vestfold. Etter alt å dømme dukker de derimot opp som Lidingum eller Lidwicingum i det anglosaksiske diktet Widsith fra slutten av 500-tallet (linje 80, Malone 1962:180) (for diskusjon og datering av Widsith, se Malone 1962; Neidorf 2013:179 og Iversen 2019). Der nevnes dessuten folk i Ranriki som Hronum. Det er noe uklart hva prefikset Lid i Lid-vikinger i Widsith henviser til, og identifikasjonen med Viken er noe usikker (Iversen 2019). Lið betegnet på norrønt et krigerfølge og ble brukt som første og andre ledd i betegnelser som har med tropper og krigerfølge å gjøre i skaldekvad og på runesteiner (se gjennomgang i Jesch 2008: 198). Det er likevel påfallende at liði m. som administrativ enhet bare forekommer i østre del av Viken, kjent fra omkring år 1200 (Ss kap. 162). Da betegnet liði en gruppe gårder som hadde ansvar for å stille og utruste en mann til leidangen - det sjømilitære forsvaret (KLNM X:534-6).

Med bakgrunn i stedsnavnet Pjóðalyng (Tjølling, Vestfold) (bjóð ‘folk', 'folkets lynghei') (Brink 2007:63) og forekomsten av Norges største kokegropfelt (på Lunde ved Tjølling) med nær 1000 kokegroper (Ødegaard 2015) har det vært argumentert for at Tjølling kan ha vært lagting for Vestfold, Vingulmark og Grenland før området ble utvidet med Ranrike på begynnelsen av 1000-tallet (Iversen 2017:260). De 30 daterte kokegropene viser at feltet var i bruk fra 380 f.Kr. til 630 e.Kr. Dersom det var et lovsamarbeid mellom fylkene på hver side av Folden (Oslofjorden) så tidlig, er det ikke usannsynlig at vår iril var en viktig person på samlingene der. Det er også sannsynlig at det var ett eller to egne fylkes- 


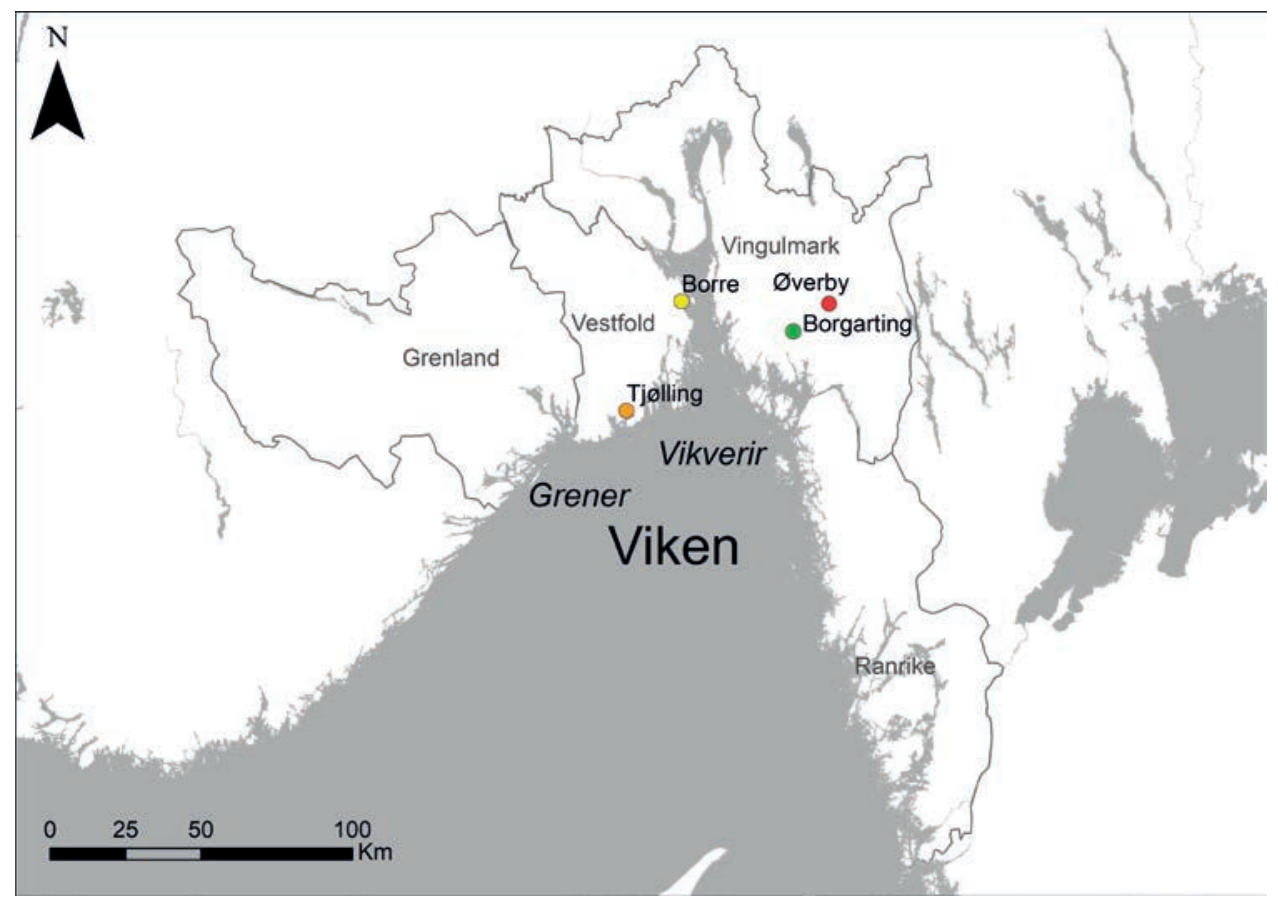

Figur 12. Borgartingslagen. Politisk, militcert og rettslig organisering i jernalderen.

Vingulmark og Vestfold kan ha dannet et kongedømme på 600-tallet med Borre som sentralt plassert kongesete. Ranrike ble integrert i Olav Haraldssons kongedømme i 1016 og underordet det nyetablerte tinget $i$ Borg, men forble utover $i$ middelalderen eget lagsogn med en viss rettslig autonomi. Grenland, Vestfold og Vingulmark kan ha dannet et eldre lagdømme med det sentrale Tjølling som hovedting der Norges største kokegropfelt (400 f.Kr.-600 e.Kr.) er funnet.

ting for Vingulmark, der Aker og Tune fremstår som mulige alternativer. Ingen av de mulige hovedtingstedene i Vingulmark fylke er arkeologisk identifisert (Ødegaard 2015) (figur 12).

Grenland synes å ha vært noe løsere tilknyttet Borgartingsområdet i forsvarssammenheng. I alle fall skiller Gulatingslovens leidangsliste, fra omkring 1150, mellom Vikverir og Grónir (grener), og spesifiserer deres bidrag til leidangen (G 315). Det kan bety at vikverene i Vestfold, Vingulmark og Ranrike hadde et felles forsvar senest på 1100-tallet.

Fylkene i Viken kan altså være svært gamle enheter. De har inngått i ulike former for allianser, kanskje allerede i eldre jernalder. Fellesskapet mellom dem ble mer formalisert gjennom lovutvikling på 1000-tallet. Grenland (militært) og Ranrike (juridisk) synes å ha hatt en noe mer autonom stilling. Hvorvidt Vingulmark og Vestfold hadde et formalisert militært, politisk og juridisk samarbeid tidligere, er uklart, men ikke usannsynlig. Dersom irilen på Øverby kan sees som en politisk og militær leder i sin samtid, er det sannsynlig at området hans var Vingulmark. Kanskje var Øverby hans sete der han kunne ta imot tilreisende konger og stormenn. I dette området ville han ha godt oppsyn med grensene for 
eventuelt å varsle videre. $\AA$ anslå at Øverby kunne være hans sete, kunne forklare hvorfor han der har reist en stein tilknyttet et gravfelt med bl.a. en kvinnegrav fra samme tid. Med bakgrunn i spenna som er funnet i gravområdet, kan İsni tolkes som et kvinnenavn. Kanskje reiste irilen monumentet for en avdød kone, mor eller datter? Bratsbergspenna viser også betydningen av en nær relasjon mellom irilen og en kvinne, mens på Rosselandsteinen fremkommer det at irilen er underordnet kvinnen Agilamundon (Johnsen 1969:45-47).

\section{Konklusjon}

I denne artikkelen har vi presentert det nye funnet av en urnordisk innskrift på Øverby i Rakkestad. Øverbyinnskriften, som dateres til 400-tallet, er den ellevte som inkluderer irilaR/erilaR. Vi har studert hele korpus med innskrifter for å forstå hvilken rolle irilen har hatt i samfunnet. Selv om usikkerhet fortsatt er knyttet til en fullstendig lesning av innskriften, kan vi slå fast at en iril reiste et stort monument med en iøynefallende runeinnskrift i et grenseområde i Vingulmark. Runene er svært store, og både steinen og innskriften må ha vært godt synlige i landskapet. For første gang i Norge har høyoppløst skanning vært brukt $i$ den første dokumentasjonen og lesningen av en runeinnskrift. Metoden med å sette nominell overflate har ikke tidligere vært utprøvd i runologisk forskning, og har gitt gode resultater. Vi ser samtidig frem til at resultatene fra vår undersøkelse kan etterprøves i materialnære undersøkelser når steinen blir tilgjengeliggjort for videre forskning (jf. Knirks anmodning om varsomhet med digital dokumentasjon i artikkelen om Kulisteinen fra 2018). I innskriften er det urnordiske ordet raskaR dokumentert for første gang, og imperativformen $l \bar{u}$ ! i urnordisk er sannsynliggjort. Gjennomgangen av alle irilar/erilaR-innskrifter har gjort det mulig å kartlegge en kronologisk og materiell distribusjon av henholdsvis de eldste innskriftene på stein med formen irilar og de yngre løsfunnene av smykker, brakteater og våpen der formen erilan opptrer. For første gang er irilan/erilan-innskriftene satt $\mathrm{i}$ en administrativ landskapskontekst, og irilen vurdert som en militær leder. Begrepene irilar/erilaR er brukt om menn med pågangsmot og andre egenskaper som var nyttige både til strid og fredelige sysler. Irilens relasjon enten til jevnbyrdige kvinner, overordnede ledere (som også kan være en kvinne, slik som på Rosseland) eller undersåtter, gjør at han fremstår som en viktig skikkelse i samfunnet. Han kan ha deltatt i og organisert krigerfølger som har kjempet f.eks. i det nåværende Danmark i romertid og folkevandringstid.

Vi mener at landskapsanalysen viser at irilens rolle først og fremst kan ha vært av kommunikativ karakter: å mobilisere i krig, holde oppsyn med grensene, varsle allierte i nabolandskap og ta imot konger på reise. Irilen på Øverby i Vingulmark var en høyt rangert leder. Runene var kanskje denne krigerens fremste våpen.

\section{Takk til}

Randi og Olav Schie for at de har tatt godt vare på runesteinen og bidratt med informasjon og for deres enestånde gjestfrihet. Emil Omenås Øvstedal, som varslet om funnet, Rakkestad avis ved Marita Berg, som varslet Fylkeskonservatoren. Harald Martin Schie, som i flere omganger har stilt opp med gravemaskin og bidratt til at steinens underside kunne undersøkes. Takk til geologene Martin Stormoen og Henrik Svensen for vurdering av bergarten. Lisbeth Imer og Michael Schulte skal ha takk for innspill og kommentarer til lesning 
av runeinnskriften, og Ingunn Røstad for bestemmelse av spenna fra Øverby. Inge Svenningsson takkes for håndholdt skanning i runde 1, Bjarte Årseth for stasjonær skanning $\mathrm{i}$ runde 3, Magne Samdal for fotogrammetri, Magnus Tangen og Jonas Nordby for deltakelse i feltarbeidet. Vi vil også takke kommunikasjonsavdelingen ved Østfold fylkeskommune og Kulturhistorisk museum for pressekontakt. Til slutt vil vi takke fagfeller og redaksjonen i Viking for nyttige kommentarer og innspill til vår tekst, en særlig takk til Kjetil Loftsgarden for hjelp med figurer.

\section{Litteratur}

Andersson, Thorsten

2009 Altgermanische Ethnika. Namn och Bygd, 5-39.

Alfsdotter, Clara, Papmehl-Dufay, Ludvig og Helena Victor

2018 A moment frozen in time: Evidence of a late fifth century massacre at Sandby borg. Antiquity 92(362):421-36.

Axboe, Alf Morten og Magnus Källström

2013 Guldbrakteater fra Trollhättan - 1844 og 2009. Fornvännen, 153-171.

Berg, Marita Lundsrud

2017 Kan ha funnet en gammel runestein. Rakkestad Avis. 6. juli 2017.

Bjorvand, Harald \& Fredrik Otto Lindeman

2019 Våre arveord: Etymologisk ordbok. 3. utgave. Instituttet for sammenlignende kulturforskning, Serie B, Skrifter 105. Novus, Oslo.

Blöndal Magnússon, Ásgeir

1989 Íslensk orðsifjabók. Reykjavík: Orðabók Háskólans.

Brink, Stefan

2007 Skiringssal, Kaupang, Tjølling - the toponymic evidence. I Kaupang in Skiringssal, redigert av Dagfinn Skre, s. 53-64. Kaupang Excavation Project Publication Series, Oslo/Århus.

Bugge, Sophus

1891 Norges Indskrifter med de celdre Runer 1. Det Norske Historiske Kildeskriftfond, Christiania.

Bøckmann, Jørgen

2000 Utgravningsrapport. Undersøkelse av bosetningsspor på Øverby Søndre, 83/1,9 og Øverby

Nordre, 83/7. Rakkestad kommune, Østfold fylke. 13. til 16. juni 2000. Upublisert rapport

Kulturhistorisk museum, Universitetet i Oslo.

Carnap-Bornheim, Cvon og Jørgen Ilkjær

1996 Illerup Ådal. Die Prachtausrüstungen. Jysk Arkceologisk Selskabs Skrifter 25, 5.6.7.8. Århus.

Carnap-Bornheim, Cvon

1997 Zur Bedeutung der militärischen Schiffahrt bei den Barbaren im 3. Jahrhundert n. Chr.

Skandinavien, die Nordsee und das Schwarze Meer. I Military Aspects of Scandinavian society in a European perspective, AD 1-1300, redigert av Anne Nørgård Jørgensen og Birthe L. Clausen, s. 226-238, Nationalmuseet, København.

Dobat, Andres S., T. Douglas Price, Jacob Kveiborg, Jørgen Ilkjær og Peter Rowley-Conwey

2014 The four horses of an Iron Age apocalypse: War-horses from the third-century weapon sacrifice at Illerup Aadal (Denmark). Antiquity 88 (339):191-204.

Ellegård, Alvar

1987 Who were the Eruli? Scandia.Tidsskrift för historisk forskning. 53(1):5-34.

Falk, Hjalmar og Alf Torp

1903-1906 Etymologisk ordbog over det norske og det danske sprog, H. Aschehoug \& Co. Kristiania.

G: Den eldre Gulatingslova. Utgitt av Bjørn Eithun, Magnus Rindal og Tor Ulset. 1994. Norrøne tekster 6, Riksarkivet, Oslo. 
Garbazc, Piotr

2016 Inskrypcja na grocie rozwadowskiej włóczni (KJ35): ik eruls czy ik erlas? LingVaria 21(1):1320.

Glørstad, Zanette Tsigaridas, Jakob Johansson og Frans-Arne Stylegar

2011 Minnelund og monument. Runesteinen på Hogganvik, Mandal, Vest-Agder. Viking 74:9-24.

Grimm, Oliver og Frans Arne Stylegar

2004 Court sites in southwest Norway. Reflection of a Roman Period political organisation?

Norwegian Archaeological Review 37(2):111-33.

Hedeager, Lotte og Henrik Tvarnø

2001 Tusen års europahistorie. Romere, germanere og nordboere. Oversatt til norsk av K.A. Lie. Pax forlag, Oslo.

Herschend, Frands

2005 Ackulturation och kulturkonflikt. Fyra essäer om järnåldersmentalitet. I OPIA. 38. Institutionen för arkeologi och antik historia. Uppsala universitet.

Hougen, Bjørn og Magnus Olsen.

1937 Runespennen fra Bratsberg i Gjerpen. Viking 1:53-73.

Ilkjær, Jørgen

1993 Illerup Ådal. Die Gürtel. Bestandteile und Zubehör. I Jysk Arkceologisk Selskabs Skrifter 25,3,4. Århus.

2000 Den første Norgeshistorien. Illerupfunnet: ny innsikt i skandinavisk romertid. Kulturhistorisk forlag, Tønsberg.

2001 Illerup Ådal. Die Schilde. I Jysk Arkceologisk Selskabs Skrifter 25, 9.10. Århus.

Imer, Lisbeth

2015 [2007] Runer og runeindskrifter: Kronologi, kontekst og funktion i Skandinaviens jernalder og vikingetid. Ph.d. avhandling, Det Humanistiske Fakultet, Københavns Universitet.

2011 The oldest runic monuments in the North - dating and distribution i NOWELE. North-Western European Language Evolution 62/63:169-212.

Iversen, Frode

2016 Estate division: social cohesion in the aftermath of AD 536-7. I The Agrarian Life of the North 2000 BC-AD 1000. Studies in Rural Settlement and Farming in Norway, redigert av Frode Iversen og Håkan Petersson, s. 41-75. Portal forlag, Kristiansand.

2017 The urban hinterland. Interaction and law-areas in Viking and medieval Norway. I Viking-Age Transformations: Trade, Craft and Resources in Western Scandinavia, redigert av Ann Zanette Tsigaridas Glørstad og Kjetil Loftsgarden, s. 250-276. Routledge, London.

2019 Between tribe and Kingdom - people, land and law in Scandza AD 500-1350. I Avaldsnes - A Sea-Kings' Manor in First-Millennium Western Scandinavia part 2, redigert av Dagfinn Skre, s.721-746. Walter de Gruyter, Berlin.

Jakobsen, Lis R. og Moltke, Erik

1942 Danmarks runeinnskrifter. Einar Munksgaard, København.

Jansson, Sven B. F.

1976 Angående Järsbergstenen. Fornvännen 72:89-95.

Jesch, Judith

2008 Ships and Men in the Late Viking Age: The Vocabulary of Runic Inscriptions and Skaldic Verse. The Boydell Press, Woodbridge.

Johansen, Øystein Koch

1989 Rakkestad bygdebok. Bind 1. Forhistorien. Oslo.

KLNM: Kulturhistorisk Leksikon for Nordisk Middelalder I-XXII, København/Oslo 1956-78.

Johnsen, Ingrid Sannes

1969 Kan runeinnskrifter bidra til å belyse kvinnens stilling i det førkristne Norden? Arkiv för nordisk filologi. 84,6,2:38-55. 
Knirk, James E

2011 Hogganvik-innskriften: en hard runologisk nøtt. Viking 74:25-39.

2018 Kuli-steinen og landsnamnet Noreg. Namn og Nemne 34:93-98.

Krag, Claus

2003 Rodulf. I Reallexikon der Germanischen Altertumskunde 25, redigert av Heinrich Beck, Dieter Geuenich og Heiko Steuer, s. 58-59, Walter de Gruyter, Berlin.

Krause, Wolfgang og Herbert Jankuhn

1966 Die Runeninschriften im Älteren Futhark. Volumes 1-2. Abhandlungen der Akademie der Wissenschaften in Göttingen, Philologisch-Historische Klasse.

Malone, Kemp

1962 Widsith. Rosenkilde og Bagger, København.

Marstrander, Carl J. S.

1952 Rosselandsteinen I. Universitetet i Bergen Arbok 1951, Historisk-antikvarisk rekke 3:1-44, Bergen.

Mees, Bernard

2003 Runic 'erilar'. North-Western European Language Evolution (NOWELE) 42:41-68.

Munch, Peter Andreas

1849 Historisk geografisk beskrivelse over Kongeriget Norge (Norgesveldi) i middelalderen. Wilhelms Grams forlag, Christiania.

1852-1853 Det norske Folks Historie, bind I-1-1 og I-1-2. Chr. Tønsbergs forlag, Christiania.

Myhre, Bjørn

1987 Chieftains graves and chiefdom territories in South Norway in the Migration Period. I Studien zur Sachsenforschung 6, redigert av Hans-Jürgen Häßler, s. 169-188, Veröffentlichungen der urgeschichtlichen Sammlungen des Landesmuseums zu Hannover 34, Hildesheim.

2015 Før Viken ble Norge: Borregravfeltet som religiøs og politisk arena. Norske Oldfunn XXXI, Kulturhistorisk museum, Universitetet i Oslo.

Nansen, Fridtjof

1911 In the Northern Mists. Artic Exploration in Early times 1 (oversatt av Arthur G. Chater). William Heinemann. London.

Neidorf, Leonard

2013 The Dating of Widsith and the Study of Germanic Antiquity. Neophilologus 97:165-183.

Nowak, Sean

2003 Schrift auf den Goldbrakteaten der Völkerwanderungszeit. Phd.-avhandling. Universität Göttingen.

Rui, Liv Marit

1986 Prøvegraving, Øverby i Rakkestad. Upublisert rapport. Kulturhistorisk museum, Universitetet i Oslo.

Røstad, Ingunn M.

2016 Smykkenes språk: smykker og identitetsforhandlinger i Skandinavia ca. 400-650/700 e.Kr. Universitetet i Oslo, Det humanistiske fakultet, Institutt for arkeologi, konservering og historie. Oslo.

2019 The Immortal Brooch. The tradition of great ornamental bow brooches in Migration and Merovingian Period Norway. I Charismatic Objects: From Roman Times to the Middle Ages, redigert av Marianne Vedeler, Ingunn M. Røstad, Elna Siv Kristoffersen, Zanette T. Glørstad, s. 73-101, Cappelen Damm Akademisk, Oslo.

Sandnes, Jørn og Ola Stemshaug

1976 Norsk stadnamnleksikon. Det Norske Samlaget, Oslo.

Schulte, Michael

2001 Metodische Überlegungen zur lexikalischen Semantik des Urnordischen. I Modalität und Mehr / Modality and More, redigert av Heinz Vater og Ole Letnes, s. 166-177, Wissenschaftlicher Verlag Trier, Trier. 
Skre, Dagfinn

1998 Herredømmet: bosetning og besittelse på Romerike 200-1350 e.Kr. Universitetet i Oslo, Universitetsforlaget.

Spurkland, Terje

2001 I begynnelsen var Futhark. Cappelen Forlag, Oslo.

Ss: Sverris saga. Oversatt av Dag Gundersen 1979. Norges kongesagaer 3. Gyldendal norsk forlag, Oslo.

Steinnes, Asgaut

1929 Kor gamal er den norske leidangsskipnaden? Syn og Segn 35:49-65.

1950 Alvheim. Historisk tidsskrift 35:353-404.

Storli, Inger

2010 Court sites of Arctic Norway: Remains of Thing Sites and Representations of Political Consolidation Processes in the Northern Germanic World during the First Millennium AD? Norwegian Archaeological Review 43(2):128-144.

Sturluson, Snorre

1979 Heimskringla. Norges kongesagaer 1-2. Oversatt av Anne Holtsmark og Didrik Arup Seip. Gyldendal norsk forlag, Oslo.

Sundquist, Olof

2009 Urnordiska erilaR - en tidig kultledare i sydvästra Skandinavien. I Järnålderens rituella platser, redigert av Anne Carlie, s. 299-316, Kulturmiljö Halland, Halmstad.

Svennung, Josef

1967 Jordanes und Scandia. Kritisch-exegetische Studien. Skrifter utgivna av K. Humanistiska vetenskapssamfundet i Uppsala 44.2 A. Stockholm.

Tacitus, Cornelius

1991 Agricola; Germania: Lateinisch und deutsch. Oversatt av Alfons Städele Sammlung Tusculum. Wissenschaftliche Buchgesellschaft, Darmstadt, Germany.

Trudsø, Susanne

2008 Runestenene i Jelling Undersøgelse af bevaringstilstand Bilag Marts 2008. http://jelling.natmus. $\mathrm{dk} /$ om-jelling/runestenene/runestenene-foer-og-nu/. Dato: 20.02.2019.

Vikstrand, Per

2013 Järnålderns bebyggelsesnamn. Om bebyggelsenamnens uppkomst och ålder i Mälarlandskapen. Institutet för språk och folkminnen. Namnarkivet i Uppsala. Serie B:13. Uppsala.

Wessén, Elias og Jansson, Sven B. F.

1940-1943 Sveriges runinskrifter: VI. Upplands runinskrifter del 1. Kungl. Vitterhets Historie och Antikvitets Akademien, Stockholm.

Ødegaard, Marie

2015 Tingsted og territorium. Organisering av rettslandskapet $i$ Viken i jernalder og middelalder. Phd.-avhandling, Universitetet i Bergen.

2018 Tinginstitusjonens alder i Skandinavia belyst ved arkeologi og stedsnavngransking - samsvar eller ikke? Viking 81:89-116.

Ånfeldt, Laila Kitzler

2010 3D-scanning at the Archaeological Research Laboratory 2006-2009. Rapporter frän Arkeologiska Forskningslaboratoriet 13. Sverige.

2013 3D-scanner analyses of the Gotland Picture Stones; Workshops, Iconography and Dating. With supplementary material: Digital catalogue of 3D-data of picture stones. JONAS : Journal of Nordic Archaeological Science 18:55-65. 


\section{Forkortelser}

$\mathrm{C}=$ Museumsnummer i Kulturhistorisk museums samling.

Hkr = Heimskringla, utgave Kongesagaer / Snorre Sturluson (oversatt av Anne Holtsmark og Didrik Arup Seip (1979), Norges kongesagaer 1-2. Oslo.

ID = nummer i Askeladden, Riksantikvarens kulturminnedatabase http://askeladden.ra.no/ 